
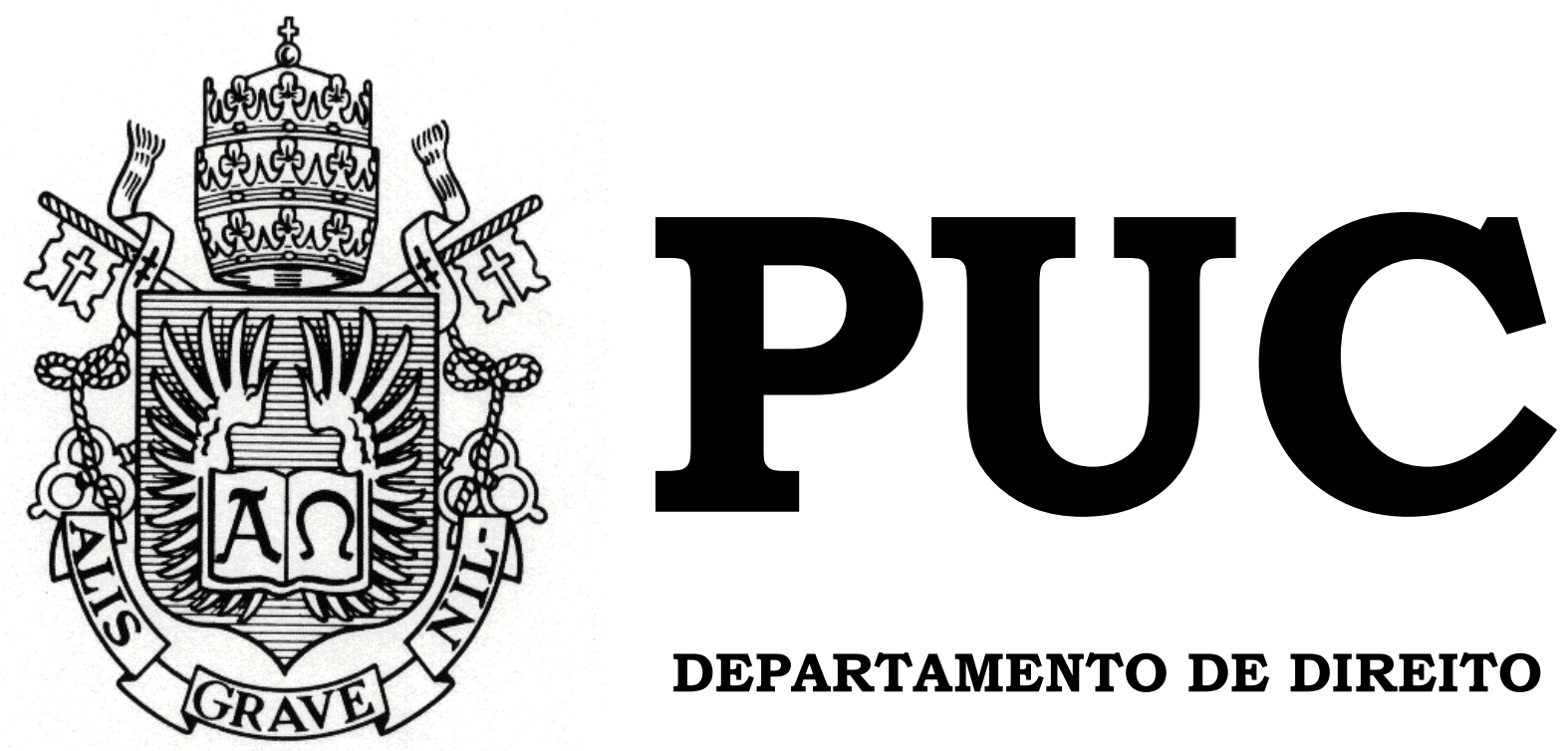

DEPARTAMENTO DE DIREITO

A Operação de Securitização de Créditos no Mercado de Capitais Brasileiro

Por

DANNY MALKA Y NEGRI

ORIENTADORA: Norma Jonssen Parente

2018.2

PONTIFÍCIA UNIVERSIDADE CATÓLICA DO RIO DE JANEIRO RUA MARQUÊS DE SÃO VICENTE, 225 - CEP 22451-900 RIO DE JANEIRO - BRASIL 


\title{
A Operação de Securitização de Créditos no Mercado de Capitais Brasileiro por
}

\section{DANNY MALKA Y NEGRI}

\author{
Monografia apresentada ao \\ Departamento de Direito da \\ Pontificia \\ Universidade \\ Católica do Rio de Janeiro \\ (PUC-Rio) como requisito \\ parcial para a obtenção do \\ título de Bacharel em Direito.
}

Orientadora: Norma Jonssen Parente

2018.2 


\section{Agradecimentos}

Antes de todos, gostaria de agradecer aos meus pais, Márcio e Elaine, por tudo o que já fizeram por mim e por meus irmãos. Por todo o suporte, atenção, carinho, dedicação, sacrifícios, e, claro, amor, que nunca faltou.

À minha irmã, Giovanna, e ao meu irmão, Eduardo. Agradeço pela nossa convivência (quase) diária, repleta de momentos de parceria e confraternização.

Necessário agradecer também aos meus avós, Mário (in memoriam) e Julieta, e Sary e Issac, que sempre se preocuparam em manter a família unida, e foram muito bem-sucedidos em mostrar a importância da família na vida de qualquer pessoa.

A todos da "Família Buscapé" que, juntos, conseguem transformar qualquer almoço monótono em família em uma divertida e irreverente tarde.

Aos meus verdadeiros amigos, - que, por muitas vezes apenas serviram para atrapalhar a confecção deste trabalho, porém sempre por bons motivos - agradeço pelos inúmeros momentos compartilhados de alegria e de felicidade, e pela certeza de que o já extenso tempo de amizade é curto perto do que vem pela frente.

Aos meus chefes, e aos meus colegas e amigos de escritório, por todo o auxílio, ensinamento e cobranças, conforme o caso. Sem dúvidas, vocês tiveram contribuição para o meu desenvolvimento profissional.

Por fim, agradeço ainda a Prof. Norma Parente, por toda a ajuda, orientação e disponibilidade, o que sem dúvidas contribuiu intensamente para o desenvolvimento do presente trabalho. 


\section{Resumo}

O presente trabalho tem por objetivo apresentar a história e o desenvolvimento das operações securitizadas, tanto em âmbito global quanto em âmbito nacional, bem como expor os principais benefícios decorrentes de uma operação securitizada, sua estrutura clássica e os principais veículos de securitização existentes no mercado de capitais brasileiro.

PALAVRAS-CHAVE: Securitização; Mercado de Capitais; Cessão de Créditos; True Sale; Fundo de Investimento em Direitos Creditórios. 


\section{SUMÁRIO}

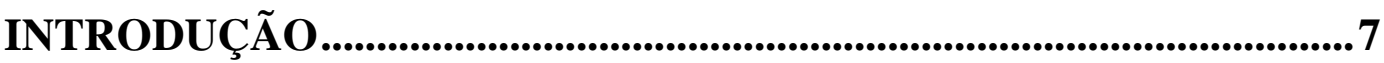

1. EVOLUÇÃO HISTÓRICA ...............................................................9

1.1. Securitização na Idade Média: Operações Embrionárias........................... 9

1.2. Desenvolvimento das operações de securitização modernas nos Estados

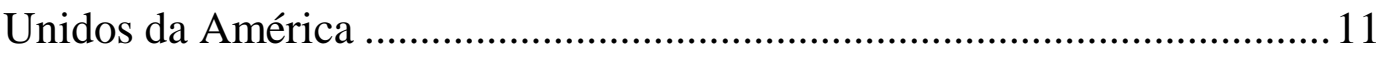

1.3. A Securitização e a Crise do Sub-Prime ……………………………...... 16

2. O MERCADO DE CAPITAIS BRASILEIRO E A SECURITIZAÇÃO NO BRASIL ................................................................22

2.1. O Mercado de Capitais no Brasil ........................................................22

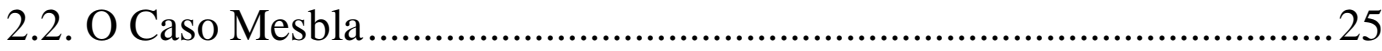

2.3. A Securitização no Mercado de Capitais Brasileiro …………………....28

3. PRINCIPAIS VANTAGENS DA SECURITIZAÇÃO ........................32

3.1. Principais Motivações para a Emissão de Títulos decorrentes de uma

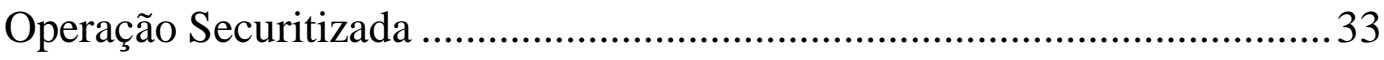

3.1.1. Redução dos custos de captação ............................................................33

3.1.2. Off-balance Sheet Financing .............................................................. 38

3.1.3. Diversificação das Fontes de Captação de Recursos ............................42

3.1.4. Transferência de Créditos de Baixa Qualidade .....................................42

3.1.5. Gerenciamento Eficaz de Capital Regulatório .....................................43

3.1.6. Liquidez e Antecipação de Receitas.....................................................45

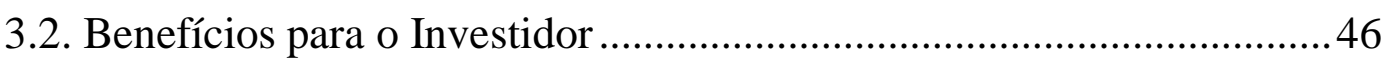

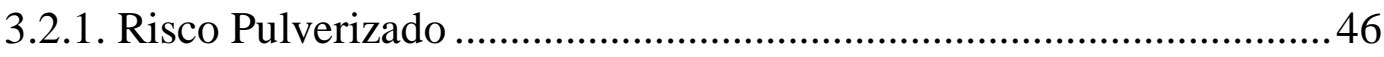

3.2.2. Segregação de Riscos e Divulgação de Informações...........................47

4. ESTRURUTRA E PRINCIPAIS VEÍCULOS DE SECURITIZAÇÃO NO MERCADO DE CAPITAIS BRASILEIRO .49

4.1. Estrutura de uma operação de securitização ………………………….....4 49

4.2. Da Cessão dos Créditos no âmbito de uma Operação Securitizada .....52

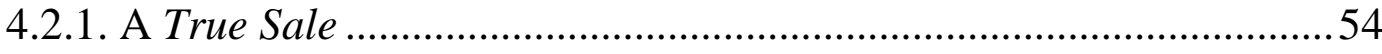

4.3. Principais Veículos de Securitização no Mercado de Capitais Brasileiro .56

4.3.1. Fundos de Investimento em Direitos Creditórios ...............................56 


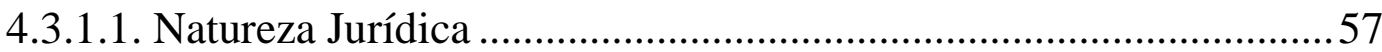

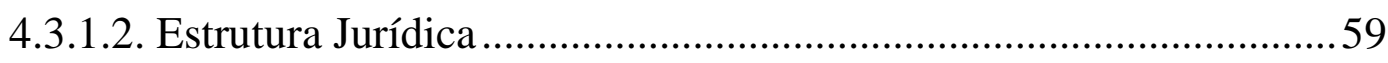

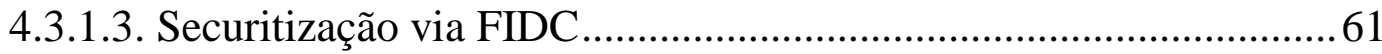

4.3.2. Fundos de Investimentos em Direitos Creditórios Não Padronizados .63

4.3.3. Da Caracterização de FIDCs como veículos de securitização............64

4.4. Companhias Securitizadoras de Crédito ..................................................67

4.4.1. Companhias Securitizadoras de Créditos Financeiros ..........................67

4.4.2. Companhias Securitizadoras de Créditos Imobiliários .........................71

4.4.2.1 Certificados de Recebíveis Imobiliários .........................................72

4.4.3. Companhias Securitizadoras de Créditos do Agronegócio...................74

4.4.3.1 Certificados de Recebíveis do Agronegócio ........................................75

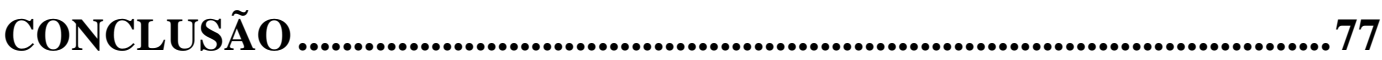

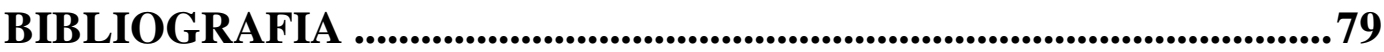




\section{LISTA DE ABREVIAÇÕES}

"ABS" - Asset Backed Securities;

"BACEN" - Banco Central do Brasil;

"DO" - Collateralized Debt Obligations;

"DS" - Credit Default Swap;

"MN" - Conselho Monetário Nacional;

"CVM" - Comissão de Valores Mobiliários;

"RA" - Certificados de Recebíveis do Agronegócio;

"CRI" - Certificados de Recebíveis Imobiliários;

"IDC" - Fundos de Investimentos em Direitos Creditórios;

"FIDC-NP" - Fundos de Investimentos em Direitos Creditórios - Não

Padronizados;

"Ginnie Mae" or "GNMA" - Government National Mortgage Association;

"GSE" - Government Sponsored Enterprises

"MBS" - Mortgage Backed Securities; 


\section{INTRODUÇÃO}

O presente trabalho pretende apresentar noções básicas sobre a securitização de créditos no âmbito do mercado de capitais brasileiro.

Para isso, faz-se necessário estudar a história das operações securitizadas, desde as suas origens na idade média até o seu desenvolvimento na idade moderna.

É importante mostrar também o desenvolvimento das operações securitizadas nos Estados Unidos da América, haja vista se tratar do maior mercado de títulos decorrentes de operações securitizadas do mundo, bem como a queda da securitização nesse país, em decorrência de uma das piores crises econômicas da história, que foi fortemente influenciada pela securitização. Os pontos acima serão abordados no primeiro capítulo, a fim de poder apresentar conceitos básicos e mostrar, ainda que preliminarmente, estruturas de securitização.

Após, no segundo capítulo, será explicado o que é o mercado de capitais, bem como será apresentado um breve histórico do mercado de capitais brasileiro. Tenciona-se também estudar um dos casos mais relevantes para o desenvolvimento da securitização no Brasil, qual seja, o caso Mesbla. Por fim, busca-se ainda apresentar brevemente dados do mercado de capitais brasileiro e das operações de securitização que nele ocorrem. Assim, ficará mais claro de se compreender o que é o mercado de capitais e como ocorrem as operações securitizadas nele.

No terceiro capítulo, objetiva-se mostrar algumas das principais vantagens que as operações de securitização trazem aos principais agentes que dela participam, visando explicar o que leva os agentes do mercado de capitais a realizarem operações securitizadas, ao invés de realizar emissões de dívidas tradicionais. 
Depois de oferecer uma base sobre os principais aspectos de uma securitização de créditos, o quarto e último capítulo do trabalho, abordará a securitização de forma mais profunda, estudando a sua estrutura clássica, os principais veículos de securitização disponíveis no mercado de capitais brasileiro e os valores mobiliários a eles atrelados. 


\section{EVOLUÇÃO HISTÓRICA}

\subsection{Securitização na Idade Média: Operações Embrionárias}

Conforme apresentado na seção de introdução deste trabalho, o objetivo deste capítulo inicial é de apresentar, ainda que de forma sucinta, o surgimento e o desenvolvimento das operações securitizadas.

Nesse sentido, é importante ressaltar que não há na literatura sobre o tema um consenso acerca da ocorrência da primeira operação securitizada da história. Existem, entretanto, relatos de operações que se assemelham à securitização desde o século XII ${ }^{1}$.

Meir Kohn, professor do Departamento de Economia da Universidade de Dartmouth, em estudo sobre a captação de recursos por longo prazo durante o período medieval europeu, vislumbrou, no século XII, na parte norte da França, operações com características semelhantes à securitização.

Segundo o autor, diante da crescente dificuldade que os senhores feudais vinham enfrentando para captar recursos, o que ocorria especialmente devido à ausência de mecanismos eficientes para recuperação de crédito $^{2}$, desenvolveu-se uma nova estrutura para captação de recursos de terceiros.

\footnotetext{
${ }^{1}$ KOHN, Meir. The Capital Market Before 1600. Dartmouth College. Department of Economics, fev. $1999, \quad$ p. 4.4 Disponível em: e1.wpmucdn.com/sites.dartmouth.edu/dist/6/1163/files/2017/03/99-06.pdf $\rangle$. Acesso em 8 de setembro de 2018.

${ }^{2}$ Nesse sentido, Meir Kohn, ao analisar brevemente as formas de garantia existentes à época explica que tanto o "pignus" (penhor) quanto a "hypothec" (hipoteca), caíram em desuso por diversos motivos, dentre eles, pelo abuso dos credores com relação aos direitos que possuíam sobre os bens que eram dados em garantia, e pela ausência de decisões judiciais que favorecessem os credores: "Perhaps because it so often ended in default, the mortgage became increasingly unpopular. Abuses by lenders were common: for example, a lender could engineer default through the simple device of making himself unavailable on the legal day of repayment. As a result, courts became increasingly sympathetic to borrowers, allowing them to redeem the property even if payment was late. " $\mathrm{KOHN}$, Meir. Op. cit., pp. 4).
} 
Por meio dessa estrutura, os senhores feudais passaram a ceder previamente pagamentos que teriam direito de receber provenientes de seus vassalos à terceiros, em troca de capital externo. ${ }^{3}$

Já no século XV, na antiga cidade-estado de Gênova, na Itália, estudiosos apontam que sempre que a cidade-estado de Gênova precisava de recursos para financiar grandes explorações, guerras ou cruzadas, a cidadeestado recorria a diversos investidores que se reuniam em um único sindicato para fornecer o capital necessário 4 .

Tais sindicatos de investidores eram chamados de compera e, em remuneração pela aplicação de seu capital, cada investidor parte de um compera recebia um título (chamado de "luoghe") que lhe dava direito a receber recursos oriundos do pagamento de tributos que seriam cobrados pela cidade-estado de seus residentes 5 .

Via-se, portanto, nas compera, algumas das características básicas da securitização, dentre elas, a utilização de um fluxo de recebíveis pulverizados como forma de remuneração aos investidores, a dispersão dos riscos pelo financiamento entre diversos investidores, e a transferência do risco de crédito do tomador da dívida para o conjunto de devedores que efetivamente irá pagar a dívida (no caso, os contribuintes de Gênova).

Não obstante ser possível identificar alguns dos elementos básicos de da securitização já no século XII, conforme evidenciado pelos estudos de Meir Kohn, não é possível afirmar que a securitização nasceu naquele momento.

Nesse sentido, alguns autores indicam que a securitização teria nascido em Amsterdam, no século $\mathrm{XVII}^{6}$, enquanto outros indicam ser

\footnotetext{
${ }^{3}$ KOHN, Meir. Op. Cit., p. 3.

${ }^{4}$ KOHN, Meir. Op. cit., pp. 9.

${ }^{5}$ KOHN, Meir. Op. cit., pp. 9.

${ }^{6}$ GOETZMANN, William N.; ROUWENHORST, K. Geert. The History of Financial Innovation, in Carbon Finance, Environmental Market Solutions to Climate Change. Yale School of Forestry and Environmental Studies, 2008, p. 18-43.
} 
possível vislumbrar exemplos de operações securitizadas no século XVIII, na Dinamarca ${ }^{7}$.

Em que pese toda a discussão sobre o nascimento da securitização e sobre as primeiras operações securitizadas realizadas, a qual, sem dúvida alguma, possui um caráter muito importante para os estudiosos da securitização, fato é que a securitização moderna surgiu, se desenvolveu e se popularizou nos Estados Unidos da América, mais especificamente, na segunda metade do século XX.

\subsection{Desenvolvimento das operações de securitização modernas nos Estados Unidos da América}

Conforme mencionado acima, a história da securitização moderna começou na segunda metade do século $\mathrm{XX}$, mais especificamente por volta da década de 70, nos Estados Unidos da América, devido à grande necessidade de crédito para o desenvolvimento do mercado imobiliário local que, na época, era incapaz de satisfazer a crescente demanda habitacional americana do pós-guerra ${ }^{8}$.

Consequentemente, o governo americano, por meio de agências governamentais e de Government-Sponsored Enterprises $(G S E S)^{9}$, passou a atuar no segmento imobiliário com objetivo de estimular a liquidez do mercado secundário e aumentar a oferta de crédito imobiliário. ${ }^{10}$

Nesse contexto, a agência governamental Government National Mortgage Association (GNMA ou Ginnie Mae) foi uma das propulsoras do desenvolvimento do mercado secundário de hipotecas, impulsionando a sua

\footnotetext{
${ }^{7}$ KOTHARI, Vinod. Securitization: The Financial Instrument of the Future. Singapura, Wiley, 2006, pp. 127-128.

${ }^{8}$ BUCHANAN, Bonnie. Back to the future: 900 years of securitization. The Journal of Risk Finance, Vol.15, $4^{\text {a }}$ Ed. 2014. p.327

${ }^{9}$ Em tradução livre: "Entidades Apoiadas pelo Governo".

${ }^{10}$ U.S. DEPARTMENT OF HOUSING AND URBAN DEVELOPMENT. The Secondary Market in Residential Mortgages. 1982. p. 12. Acesso em 31 de outubro de 2018: https://www.huduser.gov/portal/publications/hsgfin/sec_mkt_1982.html.
} 
liquidez através da aquisição de carteiras de financiamentos imobiliários garantidos por hipotecas que eram detidas por instituições financeiras privadas ${ }^{11}$.

A aquisição dessas carteiras de crédito era financiada pela emissão de títulos com lastro nos recebíveis dessas carteiras, sendo esses títulos conhecidos como "Mortgage Backed Securities"12, os quais eram subscritos no mercado de capitais norte-americano e contavam com garantia da própria GNMA, o que conferia enorme segurança aos títulos emitidos, haja vista se tratar de uma promessa de garantia indireta por parte do governo americano.

Nesse momento, instituições financeiras privadas que cumpriam determinados requisitos estabelecidos pela GNMA passaram a ter grande parte de suas carteiras de crédito imobiliário residencial vendidas para agências governamentais e por GSEs.

Consequentemente, a venda dessas carteiras de recebíveis imobiliários estimulava o mercado secundário e flexibilizava as metas de capital mínimo das instituições financeiras, que eram então voltadas para novos investimentos no segmento imobiliário, impulsionando o desenvolvimento desse setor.

Teve-se, portanto, o início do desenvolvimento das operações securitizadas modernas, haja vista a aglutinação dessas carteiras de recebíveis adquiridas e a sua posterior "conversão" em títulos distribuídos no mercado de capitais norte-americano, com a sua remuneração atrelada ao fluxo de pagamentos dos recebíveis imobiliários.

Ao passo em que o mercado imobiliário norte-americano foi se desenvolvendo em razão do maior volume de recursos disponíveis destinados à aquisição de residências próprias, o próprio mercado de capitais norteamericano foi progredindo mais também, com o aumento da emissão de

\footnotetext{
${ }^{11}$ U.S. DEPARTMENT OF HOUSING AND URBAN DEVELOPMENT. Op. cit., p. 11.

${ }^{12}$ McCONNELL, John J.; BUSER, Stephen A. The Origins and Evolution of the Market for Mortgage-Backed Securities. Annual Review of Financial Economics, n. 3, 2001, p. 176-177.
} 
mortgage-backed securities e de outros títulos relacionados ao segmento imobiliário. ${ }^{13}$

Devido ao enorme sucesso que as emissões de títulos lastreados em hipotecas estavam obtendo, grandes instituições financeiras de capital privado perceberam o potencial deste mercado e passaram a se interessar por esse tipo de operação, que, até então eram realizadas apenas por agências governamentais e GSEs.

Consequentemente, em 1977, o Bank of America foi a primeira instituição financeira privada a realizar uma operação de securitização de créditos imobiliários residenciais, a qual foi subscrita por outro gigante do mercado financeiro, o Salomon Brothers.

A partir desse momento, o número de instituições financeiras privadas que passaram a atuar nesse tipo de operações cresceu rapidamente. Foi inclusive no contexto dessa primeira emissão por uma instituição financeira privada que a palavra "securitization" (termo em inglês para a palavra "securitização") foi utilizada pela primeira vez.

Ao ser questionado por uma repórter do Wall Street Journal sobre qual nome ele daria à essa operação realizada pelo Bank of América, Ranieri Lewis, um dos principais idealizadores das operações securitizadas ao redor do mundo e ex-vice-presidente do Salomon Brothers, respondeu que a chamaria de "securitization" (palavra que na época não existia, mas que significaria transformar ativos em securities (denominação em inglês para valores mobiliários)). ${ }^{14}$

Ainda de acordo com Lewis, a palavra "securitization" foi publicada no Wall Street Journal sob protestos e com uma indicação do jornal de que a palavra seria um termo criado por Wall Street e não um termo próprio da língua inglesa. ${ }^{15}$

\footnotetext{
${ }^{13}$ U.S. DEPARTMENT OF HOUSING AND URBAN DEVELOPMENT. Op. cit., p. 33.

${ }^{14}$ VASCONCELLOS, Bernardo Fabião Barbeito de; MUNIZ, Igor. Securitização. In. Direito do Mercado de Valores Mobiliários. 1 ${ }^{a}$ Ed. Rio de Janeiro: Comissão de Valores Mobiliários, 2017, p. 694.

${ }^{15}$ Ibid. p. 694.
} 
Não obstante a origem do termo "securitização", fato é que, desse momento em diante, com instituições financeiras privadas atuando nesse mercado, o número de operações securitizadas cresceu e se desenvolveu de forma intensa, passando a representar uma fatia cada vez maior dos mercados imobiliário e de capitais norte-americano.

Para se ter uma noção, estima-se que, em 1980, o valor total da dívida representada por hipotecas residenciais nos Estados Unidos era de US\$958 bilhões e, dentro deste montante, 11\% (aproximadamente US\$105 bilhões) havia sido securitizado ${ }^{16}$.

Devido ao seu recorrente sucesso, o volume dessas operações passou a crescer ainda mais, principalmente na década de $80,{ }^{17}$ visto que as operações de securitização passaram a ter o seu escopo ampliado, atingindo outros segmentos da economia americana e deixando de ocorrer com lastro apenas em hipotecas.

Carteiras de crédito ao consumidor, de empréstimos para o financiamento de automóveis, de créditos corporativos e de crédito estudantil também passaram a ser objeto de securitização, o que contribuiu para o aumento de liquidez e para o desenvolvimento do mercado secundário de diversos segmentos, além de ter colaborado para o fortalecimento das instituições financeiras locais e para o aumento da oferta de crédito.

Explica-se: a partir do momento em que os bancos passaram a contar com a possibilidade securitizar suas carteiras de recebíveis de diversos segmentos, eles passaram a ter uma "saída" para operações de crédito que haviam sido realizadas anteriormente e que não eram mais consideradas satisfatórias para os padrões de tais bancos. Consequentemente, com o aumento de liquidez, ficou mais fácil de se desfazer dessas posições, abrindo mais espaço para realizar novas operações ativas de crédito, e, consequentemente, desenvolvendo mais o mercado.

\footnotetext{
${ }^{16}$ BUCHANAN, Bonnie. Op. Cit, p. 7.

${ }^{17}$ Outro fatores relevantes no desenvolvimento da securitização na década de 80 foram as reformas realizadas na legislação americana, incluindo a reforma tributária (introduzida pelo 1986 Tax Reform Act) e a reforma regulatória sobre o assunto. (BUCHANAN, Bonnie. Op. Cit. p. 9)
} 
Por meio dessa prática, as instituições financeiras conseguiam então retirar de seu balanço créditos que apresentassem maior risco de inadimplemento, gerenciar melhor a sua estrutura de capital mínimo e, ainda, receber de forma antecipada, ainda que com certo deságio, grande parte dos valores que receberiam se mantivessem as carteiras de créditos cedidas até o seu vencimento ${ }^{18}$.

Além das vantagens mencionadas acima, cabe destacar também que as instituições financeiras eram remuneradas pela sua atuação no segmento de estruturação e distribuição dos títulos securitizados, recebendo comissões por cada emissão que ajudavam a estruturar ou distribuir os títulos securitizados.

Desse modo, as instituições financeiras passaram a ser remuneradas em duas fases de uma operação securitizada: havia uma primeira remuneração no momento em que as instituições financeiras realizavam as operações de empréstimo (incluindo as comissões pagas no momento em que o empréstimo é originado) e, após, existia uma segunda remuneração ao vender tais créditos e securitizá-los em um momento posterior (gerando outras comissões ao atuar na cadeia de securitização).

Existia, portanto, um cenário propício para que as instituições financeiras americanas se engajassem nesse mercado e contribuíssem para o seu desenvolvimento.

Ocorre que tal operação não era vantajosa apenas para as instituições financeiras. Companhias de fora do segmento financeiro também viam benefícios em securitizar seus créditos, visto que, por meio de tal operação, seu custo de captação de recursos seria barateado.

Por fim, tais operações eram benéficas também para os próprios investidores do mercado de capitais, posto a crença de que os títulos securitizados possuíam riscos menores do que os títulos de dívida corporativa, especialmente por se tratar de um título que é pago por um

\footnotetext{
${ }^{18}$ As vantagens que a securitização pode apresentar são objeto de estudo mais aprofundado no Capitulo 3 do presente trabalho.
} 
número pulverizado de devedores, muitas vezes de diferentes segmentos e usualmente com baixas taxas de inadimplência, como era o caso dos títulos lastreados em hipotecas.

Diante todos esses fatores, a securitização havia se tornado uma das principais operações no mercado de capitais norte-americano. Estima-se que, na virada do século, havia mais de US\$1 trilhão de dólares em securitizações realizadas apenas por entidades privadas. ${ }^{19}$ Para efeitos de comparação, esse valor era aproximadamente cinco vezes maior que na Europa. ${ }^{20}$

Ocorre que, não obstante todo o desenvolvimento e o impacto positivo trazido pelas operações securitizadas nos mais diversos segmentos da economia americana, o seu crescimento desenfreado, a ausência de práticas diligentes por partes dos principais agentes do mercado envolvidos em tais operações, e a ausência de uma regulamentação sólida e de uma fiscalização eficiente por parte dos órgãos reguladores, fizeram com que a securitização se tornasse uma das principais vilãs para o desenrolar de uma das maiores crises econômicas da história.

\subsection{A Securitização e a Crise do Sub-Prime}

Em meados da década de 90 e início dos anos 2000, em consequência do avanço da engenharia financeira, as operações securitizadas passaram a evoluir e assumir formas cada vez mais complexas, de modo que novos produtos frutos de securitização vinham sendo apresentados no mercado de capitais norte-americano recorrentemente.

\footnotetext{
${ }^{19}$ SEGOVIANO, M. et al. Securitization: Lessons Learned and the Road Ahead. IMF Working Papers, 2013. Disponível em: <http://widgets.ebscohost.com/prod/customerspecific/s6115690/access/index.php?url=http\%3a\%2 f\% 2 fsearch.ebscohost.com $\% 2$ flogin.aspx $\% 3$ fdirect $\% 3$ dtrue $\% 26 \mathrm{db} \% 3$ dedsgao $\% 26 \mathrm{AN} \% 3 \mathrm{dedsgcl}$. 363191247\%26lang\%3dpt-br\%26site\%3deds-live\%26scope\%3dsite>. Acesso em: 14 out. 2018. p. 8.

${ }^{20}$ Ibid. p. 8 .
} 
Dentre os complexos instrumentos desenvolvidos, estavam os CDOs (Collateralized Debt Obligations) e os $\mathrm{CDOs}^{2}$ (Collateral Debt Obligations Squared) que eram, resumidamente, securitizações de securitizações.

Explica-se: em uma securitização "tradicional" no mercado norteamericano, o título securitizado é remunerado conforme a performance dos recebíveis de sua carteira. Tais recebíveis são usualmente representados por diversas dívidas que serão pagas por pessoas físicas e/ou pessoas jurídicas.

Um exemplo do que foi descrito acima é visto nos Mortgage Backed Securities. Os Mortgage Backed Securities são lastreados em dívidas hipotecárias contraídas por pessoas físicas ou jurídicas que são devedoras das hipotecas e os investidores detentores desses títulos são remunerados conforme o adimplemento das dívidas hipotecárias que compõem a sua carteira.

Já em um CDO, o lastro não é constituído apenas por dívidas contraídas por devedores pessoas físicas e/ou pessoas jurídicas, mas também por títulos securitizados (como Asset Backed Securities ou Mortage Backed Securities). Dessa forma, a remuneração de um CDO está necessariamente atrelada à remuneração dos títulos securitizados que compõem a sua carteira.

No caso dos $\mathrm{CDOs}^{2}$, tal título é ainda mais alavancado. Reúne-se em um $\mathrm{CDO}^{2}$, um pool de CDOs, isto é, os ativos que servem de lastro para um $\mathrm{CDO}^{2}$ são diferentes tipos de $\mathrm{CDOs}$, sendo que, muitas vezes os $\mathrm{CDO}^{2}$ são compostos por uma mistura que incluí tranches júniores ${ }^{21}$ de CDOs.

Desta forma, a remuneração dos titulares dos $\mathrm{CDO}^{2}$ fica sujeita a prévia remuneração dos CDOs que lhe serviam de lastro.

Além dos CDOs e $\mathrm{CDOs}^{2}$ (que foram apenas alguns dos complexos instrumentos financeiros desenvolvidos ${ }^{22}$ ), merecem destaque também os

\footnotetext{
${ }^{21}$ Tranches juniores são títulos cujo o pagamento é subordinado ao pagamento da tranche principal. São, portanto mais arriscados e possuem maior risco de inadimplemento. Em contrapartida, usualmente possuem retornos mais elevados do que títulos de tranches seniores.

${ }^{22}$ Nesse sentido, vale destacar que a criatividade do mercado financeiro americano não parou nos $\mathrm{CDO}^{2}$. Foram desenvolvidos e comercializados também $\mathrm{CDO}^{3}$ (CDO-Cubed) que repetem o processo dos $\mathrm{CDO}^{2}$, porém com uma camada a mais de profundidade. Seriam, portanto, títulos cujos ativos lastro eram $\mathrm{CDO}^{2}$.
} 
derivativos de modo geral, os quais tiveram enorme influência no desenrolar da crise, ao permitir que o mercado operasse de forma extremamente alavancada.

Tínhamos, de um lado, o surgimento de novos e complexos produtos no mercado que, ao passo em que podiam oferecer grandes benefícios e produzir um forte estímulo ao mercado, possuíam também um potencial destrutivo imensurável, conforme apontado por alguns dos investidores mais renomados do mercado ${ }^{23}$.

E, de outro lado, tínhamos o mercado imobiliário, um dos setores mais importantes da economia americana, que vinha se aproveitando de taxas de juros baixas estipuladas pelo banco central americano e de uma grande oferta de crédito $^{24}$ para crescer cada vez mais.

O excesso na oferta de crédito levou muitas instituições financeiras americanas a emprestarem recursos para financiamento imobiliário a um número crescente de pessoas com uma avaliação de risco de crédito ruim ${ }^{25}$, sendo, portanto, empréstimos considerados mais arriscados, e que tinham como garantia apenas a hipoteca do imóvel financiado. Tais empréstimos ficaram conhecidos como "subprime loans" e serviram de lastro para diversas operações securitizadas no mercado americano, inclusive operações que eram avaliadas com excelente rating de crédito pelas agências especializadas $^{26}$.

\footnotetext{
${ }^{23} \mathrm{O}$ investidor americano Warren Buffet, por exemplo, comentou a respeito dos risco da utilização de derivativos no relatório anual da Berkshire Hathaway, em 2002: "In my view, derivatives are financial weapons of mass destruction, carrying dangers that, while now latent, are potentially lethal", o que, em uma tradução livre significaria: "Na minha visão, derivativos são armas financeiras de destruição em massa, carregando perigos que, apesar de atualmente estarem latentes, são potencialmente letais.".

${ }^{24}$ VASCONCELLOS, Bernardo Fabião Barbeito de; MUNIZ, Igor. Op. Cit. p.698.

${ }^{25}$ Em alguns casos, o risco de crédito do devedor era tão elevado que chamavam os empréstimos de "Ninja Loans" (em tradução livre, "empréstimos ninja"), devido ao acrônimo, em inglês (No Jobs, No Income, No Assets - em tradução livre, "sem emprego, sem renda e sem ativos"), representar a situação financeira desses devedores.

${ }^{26}$ Apesar deste trabalho não abordar de forma específica a atuação das agências de rating no desenrolar da crise dos subprime, é necessário ressaltar que estas agências também possuem sua parcela de culpa. De forma resumida, pode-se dizer que tal culpa se deu principalmente na avaliação de rating de diversos títulos securitizados. Em muitos dos casos, títulos securitizados cuja carteira de recebíveis lastros era de péssima qualidade recebiam ratings elevados dessas agências, de forma
} 
Com uma forte demanda para aquisição de imóveis e com oferta de crédito suficiente para suprir essa demanda, os preços de residências foram sofrendo fortes aumentos, o que, dentre outros motivos, levou ao aumento ${ }^{27}$ da federal funds rate ${ }^{28}$, com a intenção de frear os preços aplicados no mercado imobiliário.

Ocorre que, o aumento da taxa de juros acabou acarretando em efeitos colaterais indesejados e inesperados. O aumento da taxa de juros encareceu a dívida de grande parte da população que havia tomado algum tipo de financiamento imobiliário, além disso, grande parte dos financiamentos imobiliários concedidos previa uma forma de amortização que era mais barata no início da dívida, porém mais cara com o passar do tempo.

Esses fatores levaram a um aumento na taxa de inadimplemento de financiamentos imobiliários, principalmente nos financiamentos considerados subprime. Consequentemente, a taxa de excussão das hipotecas aumentou, passando a existir em um curto espaço de tempo um enorme número de imóveis a venda, o que levou a uma queda abrupta dos preços de imóveis no mercado norte-americano, deflagrando a existência de uma bolha no mercado imobiliário norte-americano ${ }^{29}$.

A partir de então, pode-se dizer que começou um efeito cascata culminando em uma das piores crises da história recente.

Muitos americanos que haviam contraído empréstimos para poder financiar a aquisição de imóveis ficaram com uma dívida superior ao valor do próprio imóvel, e, consequentemente, os bancos passaram a ter garantias insuficientes para cobrir os valores que haviam emprestado.

\footnotetext{
que muitos investidores adquiriam esses títulos, acreditando estarem comprando títulos seguros, quando, na verdade, estavam comprando títulos de alto risco e baixo retorno.

${ }^{27}$ Nesse sentido, merece destaque que a Federal Funds Rate em junho de 2003 era de $1.00 \%$ a.a.. Esse valor aumentou em pouco mais de $125 \%$ em um ano chegando em uma taxa de $2.25 \%$, a.a., em dezembro de 2004. O crescimento foi ainda maior em 2005, atingindo, no final do ano a taxa de $4.25 \%$ a.a., e continuou ainda em 2006 , quando a atingiu uma taxa de $5.25 \%$ a.a..

${ }^{28}$ A Federal Funds Rate é a taxa de juros aplicados aos bancos em empréstimos interbancários de um dia de duração. É equivalente a Taxa SELIC no Brasil.

${ }^{29}$ VASCONCELLOS, Bernardo Fabião Barbeito de; MUNIZ, Igor. Op. Cit. p.699.
} 
Ainda, é importante lembrar que grande parte das hipotecas eram securitizadas em Mortgage Backed Securities, Collateralized Debt Obligations, ou outros títulos securitizados e, um aumento na taxa de inadimplemento dessas hipotecas tinha influência direta no pagamento desses títulos.

A partir desse momento, grande parte dos investidores de títulos securitizados passou a sofrer fortes perdas, o que levou esses títulos a perderem a maior parte de seu valor no mercado secundário, isso sem falar na crise de confiança no mercado e no sistema bancário. Além disso, em muitos dos casos, fundos geridos por instituições financeiras e as próprias instituições financeiras tinham tais títulos em carteira, de modo que essas também passaram a registrar fortes perdas.

Os derivativos, antes mencionados, ajudaram a alavancar ainda mais as perdas sofridas e a transferência de recursos para alguns poucos grupos de investidores que conseguiram antever a chegada da crise.

Nesse sentido, os derivativos de risco de credito (mais especificamente os Credit Default Swaps, ou CDSs) foram um dos propulsores dessa alavancagem.

Os CDSs surgiram como uma alternativa para oferecer proteção ao risco de crédito de terceiros, de forma que duas partes assumiam posições contrárias com relação ao risco de crédito de um terceiro em um mesmo instrumento.

A primeira parte (a parte compradora) se comprometia a realizar determinados pagamentos à parte vendedora em troca de proteção ao risco de terceiro de quem, usualmente, era credor em certas obrigações e títulos de dívida. Em contrapartida, a segunda parte (a parte vendedora) se comprometia a pagar um valor pré-estabelecido à parte compradora no caso de ocorrência de algum inadimplemento ou evento semelhante desse terceiro.

O esperado, na maioria dos casos, era que nenhum inadimplemento ocorresse, de modo que a parte vendedora iria embolsar recorrentemente os 
valores pagos pela parte compradora e, eventualmente, arcar com um ou outro inadimplemento.

Ocorre que, esse instrumento também era muito propício para especuladores e para agentes que buscavam atuar de forma alavancada, afinal não havia uma regulamentação restrita sobre ele.

Assim, era possível que agentes alocassem seus recursos em CDSs mesmo sem precisar de proteção contra o risco de crédito de terceiro, apenas para fins especulativos, e, também era possível que credores de terceiros assumissem a ponta vendedora de CDS com relação ao risco de crédito de terceiro de quem era credor, de modo que, em caso de um inadimplemento desse terceiro, o prejuízo seria dobrado (o inadimplemento e a obrigação de arcar com a posição vendedora de CDS) devido à sua exposição em dobro ao mesmo terceiro.

Dessa forma, a chegada da crise no mercado imobiliário e os seus efeitos sobre esses complexos instrumentos financeiros ajudaram a alavancar a crise que começava a surgir sobre o mercado financeiro americano.

Gerou-se um efeito dominó, em que (i) as hipotecas não eram pagas pelos seus devedores e, consequentemente, (ii) os $M B S s$ e outros títulos securitizados com lastro em recebíveis de hipoteca não eram adimplidos, e, consequentemente, (iii) os CDOs (e outros títulos com lastro em $C D O s$ ) também não eram adimplidos.

Em razão desses inadimplementos, instituições financeiras e seguradoras que atuavam como parte vendedora de CDSs se viram obrigadas a adimplir com altos e inesperados valores que eram devidos em razão de sua posição como parte vendedora de CDSs.

Houve, portanto, um colapso da economia americana. Grandes instituições financeiras faliram e outras tiveram de ser resgatadas com o dinheiro do governo americano, a taxa de desemprego subiu e a economia americana entrou em recessão. 


\section{O MERCADO DE CAPITAIS BRASILEIRO E A SECURITIZAÇÃO NO BRASIL}

Apresentada a evolução histórica da securitização e 0 seu desenvolvimento nos Estados Unidos da América, mostra-se importante mostrar as raízes da securitização no Brasil, bem como apresentar o ambiente em que tais operações são realizadas, explicando, consequentemente, o mercado de capitais, a fim de tornar a securitização mais compreensível.

\subsection{O Mercado de Capitais no Brasil}

O mercado de capitais é um dos segmentos que compõe o mercado financeiro ${ }^{30}$, sendo um ambiente composto principalmente por dois tipos de agentes: agentes deficitários (conhecidos como emissores) e agentes superavitários (conhecidos como investidores). Os primeiros desejam captar recursos, enquanto os segundos têm a intenção de aplicar seus recursos.

Neste ambiente, as vontades dos agentes se encontram e os recursos dos agentes superavitários vão de encontro à vontade de capitalização por parte dos agentes deficitários.

Tal capitalização dos agentes deficitários ocorre, primariamente, mediante a emissão de valores mobiliários pelo agente deficitário no mercado de capitais, e a subscrição e integralização destes, por parte dos agentes superavitários.

Ao contrário de outros segmentos do mercado financeiro, no mercado de capitais as instituições financeiras não atuam como agente financiador, posto que essa função é ocupada pelos investidores. As instituições

\footnotetext{
${ }^{30}$ PITTA, André Grunspun Pitta; FILHO, Valdir Carlos Pereira. Sistema Financeiro Nacional. In. Direito do Mercado de Valores Mobiliários. $1^{\mathrm{a}}$ Ed. Rio de Janeiro: Comissão de Valores Mobiliários, 2017, p. 34.
} 
financeiras atuam, via de regra, na parte de estruturação e distribuição de valores mobiliários. Isto é, a sua principal função é, via de regra, conectar os investidores aos poupadores. ${ }^{31}$

O mercado de capitais constitui, portanto, uma das mais importantes formas de desintermediação financeira existentes. A despeito da atuação de instituições financeiras nesse mercado, o seu escopo de atuação é limitado, não sendo as instituições financeiras responsáveis pela capitalização dos emissores.

Destaca-se ainda que o mercado de capitais é extremamente importante para o desenvolvimento da economia de um país. Como mencionado antes, trata-se de um segmento em que agentes superavitários ${ }^{32}$ emprestam seus recursos para agentes que desejam captar recursos, de modo que, os custos de captação tendem a ser mais baixos, especialmente se comparados aos custos de uma operação bancária tradicional, visto que a remuneração paga aos investidores costuma ser inferior à remuneração paga em operações bancárias tradicionais.

Adicionalmente, grande parte dos agentes tomadores que acessam o mercado de capitais são companhias de capital aberto com forte capacidade de movimentação de recursos na economia e com elevado número de empregados.

O mercado de capitais, por representar uma fonte segura e barata de captação é, portanto, essencial no desenvolvimento dessas empresas, o que, em troca, o torna essencial na promoção da economia de um país. ${ }^{33}$

Considerando a sua importância, é notório que este é um segmento que deve ser regulado de forma eficiente, sendo necessário sopesar os interesses de todos os agentes envolvidos. Não é razoável, portanto, um ambiente em que os investidores podem ter seus direitos frequentemente

\footnotetext{
${ }^{31}$ Ibid. p. 35.

${ }^{32}$ Nesse sentido, são agentes superavitários qualquer pessoa com recursos disponíveis para aplicar no mercado de capitais, incluindo pessoas físicas, independentemente de sua renda ou patrimônio.

${ }^{33}$ PITTA, André Grunspun Pitta; FILHO, Valdir Carlos Pereira. Op. Cit. p. 35.
} 
desrespeitados, o que poderia levar ao desinteresse destes em continuar aplicando seus recursos no mercado de capitais.

Ao mesmo tempo, seria tampouco razoável que se assumisse uma postura demasiadamente protetiva aos investidores fazendo com que os emissores fossem colocados em situações de insegurança jurídica que pudesse lhes causar riscos ou aumentar seus custos de forma direta ou indireta.

Considerando a necessidade de uma regulação eficiente para o mercado de capitais, e, levando em consideração que a Lei $n^{\circ} .4 .728$, de 1965, a principal lei que regulava o mercado de capitais brasileiro, se mostrava anacrônica ${ }^{34}$ com a intenção de desenvolver um mercado de capitais forte e moderno no Brasil, foram criadas, em 1976, duas novas normas que contribuíram e, até hoje, contribuem intensamente para o desenvolvimento do mercado de capitais brasileiro.

Tratam-se das Leis nº 6.385/1976 e nº 6.404/1976. A primeira visava regulamentar o mercado de capitais brasileiro e criou a Comissão de Valores Mobiliários, uma autarquia federal com a função de regulamentar e fiscalizar o mercado de capitais. Já a segunda tratou de modernizar a legislação aplicável às sociedades por ações.

A partir da criação destas duas leis, o país passou a contar com um arcabouço jurídico mais forte, com bases regulamentares sólidas para levar ao desenvolvimento do mercado de capitais nacional. Nesse sentido e considerando a temática do presente trabalho, é importante destacar especificamente a importância da função desempenhada pela Comissão de Valores Mobiliários.

\footnotetext{
${ }^{34}$ Nesse sentido, destaca-se que a própria Exposição de Motivos da Lei no ${ }^{\circ}$. 6.385/1976 reconheceu que, no momento da criação da Lei $\mathrm{n}^{\circ}$. 4.728/1965, o mercado de capitais brasileiro ainda era incipiente: "A Lei $n .{ }^{\circ} 4.728$, de 1965, organizou o mercado de capitais, sob a disciplina do Conselho Monetário Nacional e a fiscalização do Banco Central do Brasil. O legislador da época entendeu que o mercado de capitais, então incipiente, não justificava a criação de órgão especializado para o fiscalizar."
} 
Conforme mencionado antes, para que um mercado de capitais possa se desenvolver, é necessário que existam normas que consigam balancear os interesses dos investidores e dos emissores.

Além disso, é necessária também a existência de uma entidade que seja capaz de fiscalizar o mercado a fim de prevenir abusos por qualquer um dos seus agentes, bem como, que consiga reparar os danos que tenham sido causados por algum agente ao outro.

E, são principalmente nessas áreas em que a CVM atua ${ }^{35}$, bem como na regulação do mercado em geral, conferindo maior segurança jurídica aos investidores e aos emissores, e possibilitando que o mercado se desenvolva sustentavelmente.

\subsection{O Caso Mesbla}

Enquanto nos Estados Unidos da América as operações securitizadas começaram em meados da década de 70, no Brasil, o panorama foi um tanto quanto diferente e as operações de securitização só começaram algumas décadas depois.

Antes inclusive da realização de operações securitizadas no mercado de capitais brasileiro, algumas companhias brasileiras, como a Varig e a

\footnotetext{
${ }^{35}$ Nesse sentido, conferir as principais atribuições da CVM, de acordo com a Lei n ${ }^{\circ} .6 .385 / 76$ :

"Art. $8^{\circ}$ Compete à Comissão de Valores Mobiliários:

I - regulamentar, com observância da política definida pelo Conselho Monetário Nacional, as matérias expressamente previstas nesta Lei e na lei de sociedades por ações;

II - administrar os registros instituídos por esta Lei;

III - fiscalizar permanentemente as atividades e os serviços do mercado de valores mobiliários, de que trata o Art. $1^{\circ}$, bem como a veiculação de informações relativas ao mercado, às pessoas que dele participem, e aos valores nele negociados;

IV - propor ao Conselho Monetário Nacional a eventual fixação de limites máximos de preço, comissões, emolumentos e quaisquer outras vantagens cobradas pelos intermediários do mercado; $V$ - fiscalizar e inspecionar as companhias abertas dada prioridade às que não apresentem lucro em balanço ou às que deixem de pagar o dividendo mínimo obrigatório."
} 
Embratel $^{36}$, já acessavam, na década de 80, o mercado de capitais norteamericano para realizar operações securitizadas..$^{37}$

Já em solo brasileiro, a primeira operação relevante de securitização tais foi a operação da Mesbla Trust $^{38}$, na década de 90.

Em suma, a Mesbla S.A., uma das maiores lojas de departamento do Brasil durante grande parte do século XX, estava passando por dificuldades financeiras em razão de uma má gerencia, somada a um forte endividamento e, também, devido à conjuntura econômica do Brasil que, à época, passava por diferentes planos econômicos, muitos dos quais, afetaram fortemente o varejo. $^{39}$

Apesar de estar passando por um momento delicado financeiramente e da sua dificuldade em obter crédito, a Mesbla possuía um forte fluxo de recebíveis decorrentes de vendas realizadas a crédito através do cartão de crédito emitido por uma sociedade do seu grupo econômico. ${ }^{40}$

Com esse importante ativo em mãos, o alto escalão da Mesbla passou a buscar alternativas para tirar a companhia da situação financeira delicada em que se encontrava e, a alternativa com maior aceitação era justamente a securitização desses recebíveis.

O alto escalão da Mesbla estudou por bastante tempo o caso da loja de departamento norte-americana JCPenney que passou por problemas financeiros semelhantes aos da Mesbla e conseguiu se recuperar após realizar uma operação de securitização de recebíveis de cartão de crédito no mercado norte-americano. ${ }^{41}$

Ocorre que, ao contrário do mercado americano que possuía um grande número de investidores e legislação regulando a securitização, no

\footnotetext{
${ }^{36}$ UQBAR. Securitização. Disponível em <http://www.uqbar.com.br/institucional/emque/securitizacao.jsp. Acesso em 18 de novembro de 2018.

${ }^{37}$ VASCONCELLOS, Bernardo Fabião Barbeito de; MUNIZ, Igor Op. Cit. p.696.

${ }^{38}$ VASCONCELLOS, Bernardo Fabião Barbeito de; MUNIZ, Igor Op. Cit. p.696.

${ }^{39}$ ROCHA, R. H. Mesbla Trust de Recebíveis de Cartão de Crédito S.A.: um caso de ensino. In: Revista de Economia e Administração, v. 12, n. 4, p. 508-529, 2013. p. 509.

${ }^{40}$ ROCHA, R. H. Op. Cit. p. 509.

${ }^{41}$ ROCHA, R. H. Op. Cit. p. 511.
} 
mercado brasileiro este assunto ainda era desconhecido, e, além disso, algumas restrições legais se aplicavam a cessão e aquisição de direitos creditórios presentes e futuros. ${ }^{42}$

Considerando esse cenário, foram necessárias diversas reuniões entre o alto escalão da Mesbla e membros e representantes da Comissão de Valores Mobiliários, do Banco Central e do Conselho Monetário Nacional, até que fosse possível realizar a operação de securitização pretendida. ${ }^{43}$

A operação em si foi realizada através da emissão de debêntures por uma sociedade de propósito específico constituída justamente para isso. O grupo Mesbla constituiu a Mesbla Trust Recebíveis de Cartão de Créditos S.A., que emitiu debêntures no mercado de capitais para financiar a aquisição dos recebíveis originados pelas compras a crédito do grupo Mesbla.

A operação foi um sucesso e a Mesbla Trust Recebíveis de Cartão de Créditos S.A. conseguiu emitir debêntures com lastro nos recebíveis da Mesbla.

Não obstante a securitização ter sido bem-sucedida, ela não conseguiu fazer com que o grupo Mesbla saísse da situação financeira precária em que se encontrava. O grupo Mesbla veio a pedir concordata em meados da década de 90, no que foi uma das maiores concordatas à época.

Tal concordata veio a "testar" a estrutura de securitização planejada pela Mesbla, afinal, caso durante o processo de concordata a cessão onerosa dos direitos creditórios para a Mesbla Trust fosse anulada, os detentores das debêntures emitidas pela Mesbla Trust Recebíveis de Cartão de Créditos S.A. concorreriam com os demais credores da própria Mesbla no processo de concordata, algo que, por certo, teria efeitos nefastos no mercado de capitais brasileiro, em especial nas operações de securitização.

No entanto, a cessão dos direitos creditórios foi validada, assim como a estrutura de segregação de ativos, de modo que, a despeito da concordata

\footnotetext{
${ }^{42}$ ROCHA, R. H. Op. Cit. p. 512.

${ }^{43}$ ROCHA, R. H. Op. Cit p. 512.
} 
da Mesbla, os detentores das debêntures emitidas pela Mesbla Trust não foram prejudicados. ${ }^{44}$

\subsection{A Securitização no Mercado de Capitais Brasileiro}

Sem dúvidas a securitização realizada pela Mesbla deve ser considerada um marco para o desenvolvimento das operações de securitização no mercado de capitais brasileiro, especialmente ao se considerar que ela foi bem-sucedida para todos os agentes nela envolvidos. No entanto, como veremos adiante, este é um mercado que ainda se encontra em desenvolvimento e com um enorme potencial para ser explorado.

Como exposto antes, a securitização foi muito importante para o desenvolvimento do mercado imobiliário norte-americano e, no Brasil, é possível de se imaginar que a securitização pode trazer efeitos semelhantes.

Foi com essa intenção, inclusive, que a Lei $n^{\circ}$. 9.514, de 20 de novembro de 1997, foi baixada, criando os Certificados de Recebíveis Imobiliários (CRIs) ${ }^{45}$, o principal produto fruto da securitização de créditos imobiliários no Brasil e desenvolvendo o arcabouço jurídico a ele relacionado, desenvolvendo também normas relacionadas a propriedade fiduciária e ao regime fiduciário, muito utilizado em operações de securitização de créditos imobiliários.

Os CRIs, diga-se de passagem, são um dos instrumentos que vêm recebendo grande destaque nos últimos anos, atingindo um volume de

\footnotetext{
${ }^{44}$ CANÇADO, Thais Romano; GARCIA, Fabio Gallo. Securitização no Brasil. São Paulo: Atlas, 2007, p. 19.

${ }^{45}$ Conforme dispõe o art. $6^{\circ}$ da Lei $n^{\circ} .9 .514 / 1997$, os CRI são "título[s] de crédito nominativo, de livre negociação, lastreado em créditos imobiliários e constitui promessa de pagamento em dinheiro.", sendo de emissão exclusiva de companhias securitizadoras, conforme disposto no parágrafo único do art. $6^{\circ}$.
} 
captação de recursos de mais de $\mathrm{R} \$ 18$ bilhões $^{46}$ somente em 2016 e, com aproximadamente $\mathrm{R} \$ 76$ bilhões em estoque ao final de $2017^{47}$.

Outro produto fruto da securitização e com características semelhantes aos CRIs, porém relacionado ao segmento agrário, são os Certificados de Recebíveis do Agronegócio (CRAs).

Estes surgiram com a promulgação da Lei $n^{\circ}$. 11.076, de 30 de dezembro de 2004, e, por muito tempo, foram regidos de forma semelhante aos CRIs, utilizando-se da mesma Instrução CVM no. 414/200448, até a promulgação da Instrução CVM nº . 600, em agosto de 2018.

Ainda com relação aos CRAs, apesar da lei que os criou ter sido promulgada no final do ano de 2004 , merece destaque que a primeira oferta pública de emissão de CRAs só ocorreu no ano de $2009^{49}$, o que, sem dúvidas, retardou o seu desenvolvimento.

Ainda assim, é inegável que o CRA é um instrumento que vem crescendo em um ritmo intenso nos últimos cinco anos ${ }^{50}$, havendo, ao final de 2017, um estoque de aproximadamente $\mathrm{R} \$ 30$ bilhões em CRAs emitidos. $^{51}$

Saindo dos segmentos imobiliários e do agronegócio, os quais possuem produtos específicos como visto acima, merecem destaque também

\footnotetext{
${ }^{46}$ UQBAR. Anuário UQBAR 2018 Certificados de Recebíveis Imobiliários - 11 ${ }^{\text {a }}$ Ed. 2018, p. 19. Acesso em 4 de novembro de 2018. Disponível em: http://www.uqbar.com.br/download/UqbarAnuarioCRI2018.pdf

${ }^{47}$ UQBAR. Anuário UQBAR 2018 Certificados de Recebíveis Imobiliários - 11 ${ }^{\text {a }}$ Ed. 2018, p. 25. Acesso em 4 de novembro de 2018. Disponível em: http://www.uqbar.com.br/download/UqbarAnuarioCRI2018.pdf

${ }^{48}$ Neste sentido, a Comissão de Valores Mobiliários, em comunicado sobre o tema datado de 21 de novembro de 2008 afirmou entender "que os comandos da Instrução CVM no.414, de 2004, são adequados ao CRA e às companhias securitizadoras de direitos creditórios do agronegócio.", e que, "enquanto não tratar da matéria em norma específica, aplicará tais comandos, adaptando-os, no que couber, para acomodar as possíveis incompatibilidades entre a regulamentação de CRI e as características dos CRA e seus emissores."

${ }^{49}$ UQBAR. Anuário UQBAR 2018 Certificados de Recebiveis do Agronegócio - 11 ${ }^{\mathrm{a}}$ Ed. 2018, p. 12. Acesso em 4 de novembro de 2018. Disponível em: http://www.uqbar.com.br/download/UqbarAnuarioCRA2018.pdf.

${ }^{50}$ UQBAR. Anuário UQBAR 2018 Certificados de Recebíveis do Agronegócio - 11 ${ }^{\mathrm{a}}$ Ed. 2018, p. 12.

${ }^{51}$ UQBAR. Anuário UQBAR 2018 Certificados de Recebíveis do Agronegócio - 11 ${ }^{\mathrm{a}}$ Ed. 2018, p. 13.
} 
as debêntures emitidas por companhias securitizadoras e os fundos de investimentos em direitos creditórios.

Nesse sentido, as debêntures emitidas por companhias securitizadoras têm sido utilizadas com maior frequência nos últimos anos para a securitização de créditos financeiros ${ }^{52}$, se mostrando um eficiente meio para isso.

Além disso, outra forma de utilização de debêntures no contexto das operações securitizadas é por meio da securitização de créditos da dívida ativa dos entes federativos.

Tal prática surgiu em 2005, mas só ganhou maior atenção a partir de 2012. ${ }^{53}$ Nessas operações, entes federativos constituem companhias securitizadoras para securitizar créditos que têm a receber decorrentes do pagamento da dívida ativa. É, portanto, uma atitude digna do poder público, ainda mais ao se considerar o grave contexto econômico atual.

No total, mais de $\mathrm{R} \$ 2,5$ bilhões em recebíveis da dívida ativa dos estados já foram securitizados por meio da emissão de debêntures por companhias securitizadoras constituídas por entes da federação. ${ }^{54}$

Por fim, é necessário destacar também os FIDCs, os quais permanecem como um dos principais veículos de securitização de créditos no Brasil, com flexibilidade para adquirir diversos tipos de crédito e com um arcabouço jurídico já bem consolidado e desenvolvido no mercado, a ponto de atingir um volume de emissão de $\mathrm{R} \$ 47,74$ bilhões somente em 201755_56.

\footnotetext{
52 MEIBAK, Daniela; Debênture tira mercado de fundos de recebíveis. Valor Econômico. 3 de outubro de 2017. Disponível em: https://www.valor.com.br/financas/5142236/debenture-tiramercado-de-fundos-de-recebiveis . Acesso em 4 de novembro de 2018.

${ }^{53}$ UQBAR. Anuário UQBAR 2017 Finanças Estruturadas 2017 - Edição de 2017. 2017, p. 70-71. Acesso em 4 de novembro de 2018. Disponível em: http://www.uqbar.com.br/download/UqbarAnuarioFE2017.pdf

${ }^{54}$ UQBAR. Anuário UQBAR 2017 Finanças Estruturadas 2017 - Edição de 2017. 2017, p. 71. Acesso em 4 de novembro de 2018. Disponível em: http://www.uqbar.com.br/download/UqbarAnuarioFE2017.pdf

${ }^{55}$ UQBAR. Anuário UQBAR 2018 Fundos de Investimentos em Direitos Creditórios - $11^{\text {a }}$ Ed. 2018, p. 17. Acesso em 4 de novembro de 2018. Disponível em: http://www.uqbar.com.br/download/UqbarAnuarioFIDC2018.pdf

${ }^{56}$ Nesse ponto, é necessário destacar que o FIDC é um veículo com diversas possibilidades de investimento, não sendo utilizado exclusivamente para securitização de recebíveis, de forma que
} 
É importante destacar que o presente capitulo não abordou todas as formas de securitização existentes no mercado de capitais brasileiro, no entanto foram explanadas as principais práticas, e, conforme visto, apesar de já existir um volume elevado de títulos securitizados no mercado de capitais brasileiro, parece claro que esse número pode (e deve) crescer ainda mais. 


\section{PRINCIPAIS VANTAGENS DA SECURITIZAÇÃO}

Nos capítulos anteriores foi apresentada a evolução histórica das operações securitizadas no mercado internacional e no mercado doméstico, expondo desde as suas formas embrionárias ${ }^{57}$ (conforme evidenciado pela explicação das compera) até as suas formas mais complexas como os $\mathrm{CDO}^{3}$.

Até o presente momento, no entanto, não houve uma explicação das principais motivações que levam uma companhia a decidir se deve buscar na securitização a forma de captação de recursos de terceiros ao invés de se utilizar de outros valores mobiliários para captar recursos de terceiros.

$\mathrm{O}$ mesmo se aplica aos investidores do mercado de capitais. Por qual motivo seria mais benéfico aos investidores aplicarem seus recursos em um título proveniente de uma operação de securitização se os mesmos investidores podem aplicar seus recursos em qualquer outro produto disponível no mercado de capitais?

Destaca-se que este capítulo não tem a pretensão de trazer uma resposta absoluta aos questionamentos acima, visto que essas decisões são tomadas com base em diversos aspectos individuais, de acordo com as situações e condições específicas de cada participante do mercado.

O objetivo deste capítulo, no entanto, é de apresentar as principais vantagens da securitização, bem como os motivos que podem pesar a favor da decisão de se optar por emitir (ou adquirir, no caso de investidores) títulos decorrentes de operações securitizadas, e também, verificar se os principais benefícios apontados por estudiosos da securitização são aplicáveis no Brasil, considerando a legislação brasileira atualmente em vigor que disciplina o mercado de capitais.

\footnotetext{
${ }^{57}$ KOHN, Meir. Op. cit., p. 9.
} 


\subsection{Principais Motivações para a Emissão de Títulos decorrentes de uma Operação Securitizada}

Pode se dizer que, para uma companhia que pretende captar recursos por meio do mercado de capitais, a emissão de títulos securitizados traz diversas vantagens, as quais são usualmente vistas como parte da motivação que leva uma companhia a realizar uma operação securitizada ao invés de captar recursos por meio de outros instrumentos disponíveis no mercado.

Por mais que não seja o objeto do presente estudo focar em todos os benefícios inerentes à securitização, é necessário apresentar argumentos que evidenciem a utilidade da securitização, em meio a diversidade de instrumentos de captação de recursos existentes no mercado de capitais.

Desta forma, são listadas a seguir, e serão estudadas de forma mais profunda adiante, algumas das principais vantagens da securitização. São elas: (i) o potencial de redução de custos de captação de recursos; (ii) a possibilidade de diversificação de fontes de captação de recursos; (iii) a possibilidade de gerenciar de forma mais eficiente o risco corporativo; (iv) a maior facilidade de cumprir metas de capital regulatório mínimo (no caso de instituições financeiras); e (v) apresentação de melhores resultados no balanço contábil.

\subsubsection{Redução dos custos de captação}

Uma das principais motivações para uma companhia emitir títulos por meio de operações securitizadas é, sem dúvidas, a promessa de redução dos custos na captação de recursos. ${ }^{58}$ Surge, no entanto, uma dúvida: as operações securitizadas possuem de fato um custo de captação menor, se comparado aos outros métodos de captação de recursos disponíveis no mercado? E, caso a resposta seja positiva, por qual razão?

\footnotetext{
${ }^{58}$ SCHWARCZ, Steven L. The Alchemy of Asset Securitization, 1 Stanford Journal of Law, Business \& Finance 133-154 (1994) - p. 146.
} 
Antes de tudo, para responder as perguntas acimas deve-se levar em consideração que diversos fatores são analisados antes de uma companhia conseguir obter capital de terceiros ${ }^{59}$, seja por meio de um financiamento concedido de forma privada por uma instituição financeira, ou por meio da emissão de valores mobiliários através mercado de capitais.

Dentre esses fatores, devemos destacar que a situação financeira da companhia, a sua capacidade de geração de fluxo de caixa, os seus passivos e a sua capacidade de cumpri-los, bem como o seu setor de atuação são alguns dos pontos avaliados antes de qualquer companhia conseguir captar recursos de terceiros.

Tais fatores influenciam no momento em que uma instituição financeira ou investidores do mercado optam por emprestar seus recursos para qualquer companhia, tendo em vista que uma avaliação negativa dos fatores acima pode demonstrar que a companhia que deseja captar recursos terá maior dificuldades na hora de repagar os valores que the foram emprestados. Consequentemente, para que a aplicação dos recursos do credor seja satisfatória, é de se esperar que a sua remuneração será superior à média, tendo em vista o maior risco que companhia que está buscando recursos oferece. Em decorrência da remuneração mais elevada a ser auferida pelo credor, o preço a ser pago pelo devedor ao captar tais recursos será mais elevado.

Por outro lado, uma companhia que possui uma boa avaliação de crédito e que seja capaz de fornecer maior segurança de que terá a capacidade de repagar pontualmente os valores que lhe foram emprestados tende a pagar uma remuneração menor pelo empréstimo que lhe for feito, de forma que, o custo de captação de recursos por tal companhia será menor.

E, é neste segundo caso que se encaixa uma operação securitizada. Conforme exposto anteriormente, no caso Mesbla e na parte histórica das

59 Nesse aspecto, define-se: "Como capital de terceiros ou capital de crédito podem ser compreendidos os valores provenientes de financiamento externo da atividade ou "obtidos de terceiros para aplicação no empreendimento"". (DINIZ, Gustavo Saad. Instrumentos de Capitalização Societária. In: Revista de Direito Privado, vol. 49/2012, p. 315). 
operações securitizadas, os preceitos clássicos da securitização preveem a constituição de um veículo de propósito específico para a aquisição de uma carteira de recebíveis. Essa aquisição é financiada mediante a emissão de determinados títulos no mercado de capitais pelo veículo de propósito específico.

Nota-se, portanto que o veículo que emitirá os títulos é um novo ente legal constituído especificamente para a efetivação da operação securitizada. É, portanto uma nova pessoa jurídica, com patrimônio distinto dos seus controladores, sendo apenas uma "casca" sem qualquer tipo de passivo préexistente que possa ser considerado relevante diante de qualquer análise, Desta forma, a análise de crédito que será realizada sobre o emissor será limitada a, praticamente, apenas a carteira de recebíveis que irá lastrear os títulos a serem emitidos.

Não existirão, portanto, riscos ou contingências apresentados por tal veículo, assim como não deve haver preocupação sobre o seu gerenciamento e sobre as suas atividades futuras. Desta forma, o "custo de monitoramento"60 do credor será baixo - especialmente se comparado ao custo de monitoramento de um empréstimo tradicional -, tendo em vista que o mesmo não precisará monitorar as atividades do emissor do título, visto se tratar de uma "casca" apenas, sem atividades operacionais.

Dessa forma, uma companhia que deseja captar recursos de terceiros e que está passando por uma situação financeira delicada, pode ter na securitização uma forma mais barata de obter recursos, visto que, ao contrário de um empréstimo tradicional, no qual o processo de diligência realizado pelas instituições financeiras apontaria riscos na concessão de crédito e as instituições financeiras, consequentemente cobrariam uma remuneração proporcional a estes riscos, em uma operação securitizada, praticamente apenas a carteira de recebíveis será analisada e utilizada como base para a estipulação da remuneração dos investidores.

${ }^{60}$ SCHWARCZ, Steven L. Op. Cit. p. 150. 
O mesmo se aplica a uma companhia avaliada por agências de rating que não consegue alcançar a nota máxima de crédito. Se essa companhia tentar obter um financiamento ou tentar levantar recursos por meio do mercado de capitais, a tendência é que seu custo de captação seja mais elevado do que o custo de captação de uma companhia com um rating superior ao seu.

No entanto, por meio de uma operação securitizada, será possível a colocação de títulos no mercado com um rating superior àquele da sociedade originadora dos créditos, o que, por si só, já reduzirá os seus custos de captação de recursos. ${ }^{61}$

Ou seja, resta estabelecida a lógica que comprova que por meio da securitização de créditos, é possível que qualquer companhia com uma carteira de recebíveis, independentemente de sua situação financeira ou de sua avaliação de rating, ${ }^{62}$ consiga captar recursos de terceiros por meio do mercado de capitais por preços mais baixos do que conseguiria através de um financiamento junto à instituições financeiras ou por meio da emissão de outros títulos no mercado de capitais. ${ }^{63}$

Explicada a lógica por que permeia a diminuição dos custos de captação em uma operação securitizada, cabe trazer exemplos que sustentem tal argumentação na prática, especialmente ao se considerar que essa é uma das principais vantagens e motivações para a realização de securitizações.

Nesse sentido, vale destacar a existência de estudo realizado no cenário acadêmico brasileiro que, após analisar diversas emissões de quotas

\footnotetext{
${ }^{61}$ FABOZZI, Frank J.; KOTHARI, Vinod. Introduction to Securitization. New Jersey: Jon Wiley \& Sons, Inc., 2008. p. 15-16.

${ }^{62}$ Neste sentido, vale destacar que, apesar de qualquer companhia conseguir captar recursos a custos mais baratos, as principais companhias a se utilizar de estruturas de securitização são as companhias com pior rating, conforme estudo realizado pela Associação Nacional de Pós-Graduação e Pesquisa em Administração: "Na análise da segunda hipótese testada, foi possível encontrar evidências de que empresas com piores ratings securitizam mais. Tal resultado mostra-se alinhado com a literatura abordada e coerente com os benefícios esperados da securitização dado que esta deveria ser mais vantajosa a empresas com maiores custos de captação ou piores indicadores financeiros, fatores refletidos nos ratings." (FERNANDES, Mauricio Palmada, Et. al., A Securitização, Rating de Crédito e Valor de Empresas Emissoras.) Disponível em http://www.anpad.org.br/admin/pdf/FIN91.pdf. Acesso em 13 de outubro de 2018)

${ }^{63}$ FABOZZI, Frank J.; KOTHARI, Vinod. Op. Cit. p. 14.
} 
de Fundos de Investimento em Direitos Creditórios (FIDCs) - conforme será visto adiante, um dos produtos mais utilizados em operações securitizadas no mercado de capitais brasileiros - conseguiu observar diversas emissões em que as sociedades originadoras de créditos estruturaram um FIDC com um rating superior ao seu próprio rating. ${ }^{64} 65$

$\mathrm{O}$ mesmo estudo concluiu que a diferença nas avaliações de rating ocorria principalmente devido à diferença nos riscos de crédito ${ }^{66}$. Enquanto os FIDCs possuem um risco de crédito praticamente limitado a sua própria carteira de recebíveis, as sociedades originadoras possuem diversos outros riscos e passivos que devem ser levados em consideração.

Vale destacar também um estudo preparado em 2014, por pesquisadores da Universidade Tecnológica de Michigan, no qual se chegou à conclusão de que a securitização de contratos de energia fotovoltaicos constituiria um meio eficaz de redução custos de captação de recursos para projetos fotovoltaicos, podendo a securitização reduzir os custos de captação entre $5 \%$ e $13 \% .{ }^{67}$

Por fim, um relatório preparado por membros do Fundo Monetário Internacional (FMI) (International Monetary Fund - IMF) que discorre sobre o passado recente e sobre o futuro da securitização denominado

\footnotetext{
${ }^{64}$ PULINO, M. V. Z. O custo de capital em operações de securitização de recebíveis de empresas não-financeiras por meio da emissão de quotas de Fundos de Investimento em Direitos Creditórios - FIDCs. São Paulo, 2010. Dissertação (Mestrado em Administração de Empresas). Coordenadoria de Pós-Graduação, Fundação Getúlio Vargas, Escola de Administração de Empresas de São Paulo. p. 62.

${ }^{65}$ Merece destaque também a seguinte reportagem, na qual, em um cenário no qual está se discutindo a securitizando de recebíveis, um dos participantes do mercado discorre que: "(...) na estrutura dos FIDCs, o tomador pode obter um rating superior ao de uma debênture e com isso reduzir o custo do funding. Isso porque os FIDCs têm uma estrutura em que o risco de crédito está nos recebíveis e não na companhia que os está cedendo e ainda, têm um colchão de liquidez da cota subordinada. Como exemplo, ele diz que, enquanto um emissor com rating BBB eventualmente captaria a um custo em torno de 5\% a $6 \%$ somado ao CDI com debêntures, poderia estruturar um FIDCs com rating AAA oferecendo retorno de 2,5\% a 3\%.". (ESTADÃO CONTEÚDO. Cias driblam buscam na securitização opção para financiamento. IstoÉ Dinheiro. 6 de junho de 2015. Acesso em 30 de outubro de 2018.2 Disponível em: https://www.istoedinheiro.com.br/noticias/economia/20150906/cias-driblam-buscamsecuritizacao-opcao-para-financiamento/296338)

${ }^{66}$ PULINO, M.V.Z., Op. Cit.. p. 62.

${ }^{67}$ ALAPHITA, T.; PEARCE, J.M. Securitization of Residential Solar Photovoltaic Assets: Costs, Risks and Uncertainty. Energy Policy. Volume 67 - Abril/2014. p. 495.
} 
"Securitization: Lessons Learned and the Road Ahead"68 reconhece que a securitização é uma forma eficiente de captar recursos por custos mais baixos. ${ }^{69}$

\subsubsection{Off-balance Sheet Financing}

Outro importante benefício que uma operação de securitização pode trazer é o chamado "off-balance sheet financing" (em uma tradução livre, "financiamento não retratado no balanço patrimonial"), o que, em uma explicação simples - como o próprio nome sugere-, seria a não representação de determinadas obrigações no balanço patrimonial de uma companhia.

Merece destaque que, ao contrário de antigamente, em que a caracterização de diversas formas de securitização como financiamentos offbalance sheet ocorria de forma recorrente, hoje em dia essa prática é menos vista.

Já há alguns anos, passou a haver uma fiscalização mais extensiva por parte dos agentes reguladores às operações off-balance, de forma que, atualmente, para que uma operação securitização seja considerada uma operação off-balance sheet, ela deve cumprir alguns requisitos, como será visto adiante.

Não obstante o disposto acima, essa prática ainda pode se mostrar muito vantajosa para as companhias.

Um exemplo das vantagens que podem ser auferidas se dá devido ao fato de a companhia que capta os recursos não ter um aumento nos seus índices de endividamento e, consequentemente, ter uma análise de risco de crédito melhor avaliada por instituições financeiras e pelo mercado

\footnotetext{
${ }^{68}$ SEGOVIANO, M. et al. Securitization: Lessons Learned and the Road Ahead. IMF Working Papers, 2013.2 Disponível em: <http://widgets.ebscohost.com/prod/customerspecific/s6115690/access/index.php?url=http\%3a\%2 f $\% 2$ fsearch.ebscohost.com $\% 2$ flogin.aspx $\% 3$ fdirect $\% 3$ dtrue $\% 26 \mathrm{db} \% 3$ dedsgao $\% 26 \mathrm{AN} \% 3 \mathrm{dedsgcl}$. 363191247\%26lang\%3dpt-br\%26site\%3deds-live\%26scope\%3dsite>. Acesso em: 14 out. 2018. ${ }^{69}$ Ibid. p. 6.
} 
financeiro em geral, o que pode reduzir futuros custos de captação de recursos.

Outro exemplo do seu benefício reside no fato de que diversas companhias possuem contratos (principalmente contratos financeiros) com cláusulas restringindo o seu endividamento à certos níveis pré-determinados durante a vigência do contrato (tais cláusulas são denominadas "covenants financeiros").

Esses covenants financeiros, por sua vez, são verificados de acordo com os balanços patrimoniais das companhias.

Portanto, por meio de um financiamento off-balance, a partir do momento em que determinados recursos entram no balanço patrimonial de uma companhia de forma diversa de um financiamento ou uma dívida (como uma venda de ativos, no caso de certas formas de securitização), a companhia estaria se capitalizando sem descumprir qualquer covenant financeiros.

Nota-se então que, por meio do financiamento off-balance sheet há uma melhora na apresentação do balanço patrimonial de uma companhia, bem como de seus níveis e índices financeiros, aparentando a companhia estar em uma situação financeira mais saudável. ${ }^{70}$

A despeito desta prática poder ser extremamente benéfica para uma companhia, ela traz consigo alguns riscos, especialmente ao mercado e aos investidores, como se vislumbrou no escândalo global da companhia américa Enron, uma das maiores do mundo no segmento de energia. ${ }^{71} 72$

Nesse sentido, por mais que não tenha sido possível verificar a realização de operações securitizadas por parte da Enron ${ }^{73}$, é inegável que as

\footnotetext{
${ }^{70}$ KOTHARI, op. cit. p. 19.

71 Para maiores informações sobre o escândalo envolvendo a Enron, ver: https://economia.estadao.com.br/noticias/geral,o-escandalo-da-enron-saiba-o-que-estaacontecendo,20020207p24521. Acesso em 4 de novembro de 2018.

${ }^{72}$ Neste aspecto, é importante ressaltar que não é possível atribuir por completo a culpa do escândalo envolvendo a Enron à prática de operações financeiras off-balance sheet. Uma atribuição de culpa mais adequada (ainda que simplória) seria a prática de uma contabilidade fraudulenta que também utilizou das mais diversas formas de operações off-balance sheet.

73 SCHWARCZ, Steven, L. Securitization Post-Enron. United States, North America: Duke University School of Law, 2004.
} 
operações securitizadas, assim como diversas outras práticas dos mercados financeiros ao redor do mundo foram impactadas por este escândalo.

Após este escândalo, passou a haver uma fiscalização mais forte sobre operações off-balance sheet e as normas contábeis tornaram-se mais rigorosas, especialmente com relação aos veículos de propósito específico ${ }^{74}$.

No Brasil, o tratamento não foi diferente. A Lei nº. 6.404/1976 prevê no parágrafo único do artigo 250 que a Comissão de Valores Mobiliários pode expedir normas sobre a consolidação dos resultados de controladas no balanço contábil de uma companhia de capital aberto.

E, foi isso que a Comissão de Valores Mobiliários fez, em 18 de agosto de 2004, ao baixar a Instrução CVM n ${ }^{\circ} .408^{75}$, a qual regula a inclusão de veículos de propósito específica nas demonstrações financeiras de uma companhia de capital aberto. ${ }^{76}$

Tal norma foi baixada justamente com o objetivo de aprimorar as normas contábeis utilizadas no Brasil, seguindo as orientações emitidas pelo IASB - International Accounting Standard Board e pelo FASB - Financial Accounting Standard Board, adequando, portanto, os padrões brasileiros às melhores práticas contábeis que vinham sendo utilizados ao redor do mundo. ${ }^{77}$

A partir desse momento, as companhias de capital aberto que constituíam um veículo de propósito específico com o objetivo de securitizar

\footnotetext{
${ }^{74}$ KOTHARI, op. cit. p. 19.

${ }^{75}$ Conforme se verifica pela leitura do Art. $1^{\circ}$ da Instrução CVM no. 408: "Art. 1o Para fins do disposto na Instrução CVM no 247, de 27 de março de 1996, as demonstrações contábeis consolidadas das companhias abertas deverão incluir, além das sociedades controladas, individualmente ou em conjunto, as entidades de propósito específico - EPE, quando a essência de sua relação com a companhia aberta indicar que as atividades dessas entidades são controladas, direta ou indiretamente, individualmente ou em conjunto, pela companhia aberta."

${ }^{76}$ Vale destacar que na Nota Explicativa à Instrução CVM n ${ }^{\circ}$. 408, a CVM reconheceu a importância dos veículos de propósito específico nas operações de securitização de ativos financeiros

${ }^{77}$ Conforme se depreende da Nota Explicativa à Instrução CVM n ${ }^{\circ} .408:$ "Importante é mencionar que esta norma se insere no objetivo da CVM em buscar uma harmonização das práticas contábeis brasileiras com as normas contábeis internacionais, alinhando-se, no presente caso, às orientações emitidas pelo IASB - International Accounting Standard Board (SIC no 12, emitido em novembro de 1999) e pelo FASB - Financial Accounting Standard Board (Fasb Interpretation $n^{\circ} .46$, emitido em janeiro de 2003)."
} 
seus créditos passaram a ter de incluir os resultados financeiros desses veículos de propósito específico em seu balanço patrimonial consolidado.

Portanto, a partir do momento em que um veículo de propósito específico emitia títulos de dívida securitizados no mercado de capitais, tal veículo estava contraindo uma dívida e tal dívida deveria ser representada em seu balanço contábil.

Consequentemente, a partir do momento em que os resultados desse veículo de propósito específico eram consolidados no balanço contábil do seu controlador - que, normalmente era a sociedade originadora dos créditos cedidos ao veículo - a dívida decorrente da emissão dos valores mobiliários securitizados por tal veículo de propósito específico também passaria a ser retratada no balanço contábil da sociedade originadora de créditos, ainda que, não necessariamente como uma dívida da própria sociedade originadora, mas sim de uma de suas controladas.

Nota-se, no entanto que, caso uma sociedade originadora de créditos consiga estruturar uma securitização utilizando um veículo de propósito específico que não tenha qualquer vínculo societário com a própria sociedade originadora e com as demais companhias de seu grupo societário e, desde que a venda dos créditos constitua uma forma efetiva de true sale ${ }^{78}$ que não conte com retenção de riscos, este tipo de financiamento, a princípio, não será retratado em seu balanço patrimonial, constituindo assim uma forma de offbalance sheet financing ${ }^{79}$.

\footnotetext{
${ }^{78}$ MENDES, Hélio Rubens de Oliveira. Securitização de crédito e a lei $n^{\circ} 11.101 / 05.2014$. Tese (Doutorado em Direito Comercial) - Faculdade de Direito, Universidade de São Paulo, São Paulo, 2014, p. 61-62.

${ }^{79}$ GELBCKE, Ernesto Rubens et al. Manual de contabilidade societária: aplicável a todas as sociedades, de acordo com as normas internacionais e do CPC. 3.ed. São Paulo: Atlas, 2018. p. $129-130$
} 


\subsubsection{Diversificação das Fontes de Captação de Recursos}

Outro ponto que pode ser considerado atrativo para a estruturação de uma operação securitizada é a possibilidade de diversificação das fontes usuais de captação de recursos. ${ }^{80}$

Ou seja, ao invés de recorrer aos próprios acionistas, à instituições financeiras, ou até mesmo ao próprio mercado de capitais por meio da emissão de títulos de dívida própria, quando uma sociedade realiza uma operação de securitização de créditos, ela diversifica o seu portfólio de dívidas e de credores, diminuindo dessa forma a sua exposição junto aos seus credores, passando a ter maior independência e poder de barganha perante tais credores.

Outro ponto levantado é a possibilidade de consolidação de seu nome no mercado de capitais, o que pode fazer com que uma futura emissão de títulos no mercado seja melhor recepcionada. ${ }^{81}$

\subsubsection{Transferência de Créditos de Baixa Qualidade}

Conforme visto antes, um dos passos essenciais em uma securitização é a cessão de recebíveis de uma sociedade originadora para um veículo de propósito específico.

Por óbvio, a sociedade originadora dos créditos, ao ceder os recebíveis deverá escolhe-los de forma adequada, haja visto que a emissão de um valor mobiliário decorrente de uma securitização consistindo apenas de recebíveis de qualidade baixa não tende a ser tão atrativa aos olhos do mercado, correndo o risco de haver baixa demanda e de ser necessária a estipulação de uma remuneração mais elevada para compensar pela baixa qualidade de tais recebíveis.

\footnotetext{
${ }^{80}$ KOTHARI, Vinod. Op. Cit. p. 17.

${ }^{81}$ Ibid. p. 17.
} 
No entanto, é inegável que a sociedade originadora dos créditos possui alguma flexibilidade para incluir dentro do pacote de recebíveis que serão cedidos alguns recebíveis de qualidade inferior sem que isso contamine a emissão.

Ademais, é possível que existam avaliações distintas da qualidade e do valor dos recebíveis cedidos entre a agência de rating que avaliará o valor mobiliário a ser emitido, e a sociedade originadora dos créditos, sendo possível, portanto que a sociedade originadora retenha recebíveis que em sua visão são superiores àqueles avaliados pela agência de rating.

Dessa forma, a sociedade originadora dos créditos transfere aos investidores o risco de crédito dos devedores dos recebíveis. ${ }^{82}$

Vale mencionar também que, haja vista o grau de discricionariedade da sociedade originadora de créditos, e a estrutura definida para a securitização, é possível também que sejam securitizados créditos que já estejam inadimplentes ou que sejam provisionados como créditos de liquidação duvidosa, o que pode vir a impulsionar o balanço patrimonial da sociedade originadora de créditos.

\subsubsection{Gerenciamento Eficaz de Capital Regulatório}

Sob o ponto de vista das instituições financeiras que cedem seus créditos em operações de securitização, há ainda um interessante aspecto da securitização brevemente mencionado no primeiro capítulo. Trata-se do gerenciamento do capital regulatório.

Conforme já apresentado, a crise do subprime expôs diversos problemas na regulação bancária global, e, visando sanar essas falhas na regulação bancária, diversos bancos centrais ao redor do mundo acordaram

\footnotetext{
${ }^{82}$ Ibid. p. 18.
} 
em incorporar os princípios provenientes do Acordo de Basileia III ${ }^{83}$, aos seus respectivos sistemas financeiros.

O Conselho Monetário Nacional, por exemplo, baixou por meio do Banco Central do Brasil, dentre outras, as Resoluções nº 4.192 e nº. 4.193, visando adequar o sistema bancário nacional aos princípios estabelecidos no Acordo de Basileia III.

Consequentemente, as normas prudenciais sobre manutenção de capital regulatório de instituições financeiras tornaram-se mais rígidas, sendo necessário dispensar maior atenção aos empréstimos e financiamentos mantidos nas carteiras das instituições financeiras, especialmente aqueles de baixa qualidade, haja vista a necessidade de assegurar maior parcela de capital para manter esse crédito. ${ }^{84}$

Ocorre que, sob esse aspecto, a securitização apresenta uma alternativa que pode ser bem atrativa para as instituições financeiras. Conforme visto, por meio da securitização há uma cessão de créditos da carteira de uma sociedade originadora para um veículo de propósito específico.

Dessa forma, quando uma instituição financeira cede créditos que mantem em sua carteira no âmbito de uma operação securitizada, ela está abrindo espaço para realizar novas operações financeiras ativas, que podem vir a apresentar uma remuneração superior, sem criar qualquer impacto nas suas metas de capital regulatório.

Além disso, há a possibilidade de uma instituição financeira securitizar uma carteira de créditos de diferentes qualidades (incluindo créditos de liquidação duvidosa), cujo título emitido venha a ser atribuído com um bom rating.

\footnotetext{
${ }^{83}$ ASSOCIAÇÃO BRASILEIRA DAS ENTIDADES DOS MERCADOS FINANCEIRO E DE CAPITAIS. Basileia III no Brasil.. Disponível em: < http://www.anbima.com.br/pt_br/informar/regulacao/informe-de-legislacao/basileia-iii-nobrasil.htm\#tit2_3> Acesso em 20 de outubro de 2018.

${ }^{84}$ Ibid. p. 18.
} 
Neste caso, sob o ponto de vista do capital regulatório de uma instituição financeira, pode ser melhor inclusive manter este título securitizado em sua carteira do que manter os empréstimos e financiamentos que deram origem ao título securitizado. ${ }^{85}$

\subsubsection{Liquidez e Antecipação de Receitas}

Conforme explicado anteriormente, não é o objetivo do presente trabalho abordar e explicar de forma minuciosa todas as vantagens que uma operação de securitização pode trazer para o seu originador, especialmente porque cada operação é estruturada de forma diferente, com características e benefícios próprios.

No entanto, em adição aos benefícios acima, vale também apontar de forma sucinta mais dois benefícios que o originador pode ter em uma operação securitizada.

O primeiro é a possibilidade de transformar ativos ilíquidos, quais sejam os recebíveis de uma companhia, em ativos com maior liquidez ${ }^{86}$.

Neste caso, se a sociedade originadora dos créditos adquire parte dos valores mobiliários emitidos no âmbito da operação securitizada, pode-se argumentar que, além dos outros benefícios mencionados acima já obtidos, tal companhia ainda faz uma troca de ativos ilíquidos (no caso, os recebíveis) por ativos com uma liquidez maior (no caso, os valores mobiliários decorrentes da securitização).

Nesse sentido, a despeito do mercado secundário de valores mobiliários ainda estar em fase de desenvolvimento, o simples fato de se substituir ativos ilíquidos por valores mobiliários já representa uma troca benéfica ao originador, especialmente ao se considerar todas as características inerentes aos valores mobiliários, como a sua padronização, a

\footnotetext{
${ }^{85}$ Ibid. p. 19.

${ }^{86}$ KENDALL, L. T.; FISHMAN, M. J. A Primer on Securitization. Cambridge, Mass: The MIT Press, 1996, p. 13.
} 
sua facilidade de negociação e a sua admissão em mercados regulamentados, o que, sem dúvidas já representa uma facilidade maior de revenda do que se espera de uma carteira de ativos ilíquidos.

Por fim, destaca-se um último aspecto que se considera relevante, o qual seja, a antecipação de receitas por parte da sociedade originadora dos créditos.

A partir do momento em que a companhia vende uma carteira de recebíveis para um veículo de propósito específico, essa companhia terá um aumento imediato em sua receita, ao contrário do que ocorreria caso esperasse para receber todos os recebíveis cedidos.

Sobre este aumento imediato na receita da companhia, é possível vislumbrar alguns pontos positivos e negativos.

Um ponto positivo seria que o aumento na receita da companhia tende a melhorar os seus resultados financeiros, aumentando, portanto, a possibilidade de que haja uma distribuição de lucros aos acionistas da companhia, bem como, valorize a companhia perante os olhos do mercado, devido aos seus resultados financeiros mais atrativos.

Por outro lado, essa antecipação de receitas pode vir a ter um impacto negativo sobre o fluxo de caixa da companhia, bem como, gerar a necessidade de antecipar também o pagamento de tributos.

\subsection{Benefícios para o Investidor}

Não obstante os pontos enumerados acima, os quais mostram os benefícios que o originador dos créditos pode obter com uma operação securitizada, a fim de realizar um trabalho mais completo, mostra-se necessário também apresentar os principais benefícios que um investidor pode obter ao adquirir valores mobiliários securitizados.

\subsubsection{Risco Pulverizado}


Uma das principais vantagens que o investidor tem ao adquirir títulos securitizados reside, sem dúvidas, no fato de que o risco de crédito associado ao título securitizado tende a ser pulverizado.

Ao contrário de uma emissão de dívida convencional no mercado de capitais em que o investidor, ao adquirir o título está aceitando o risco de crédito de uma contraparte (e, conforme o caso, dos garantidores do título), em uma operação securitizada, os pagamentos decorrentes do título ocorrem conforme o fluxo de pagamento dos recebíveis cedidos, e, via de regra, estes pagamentos são realizados por diversos devedores diferentes.

Desta forma, pode-se dizer que o risco de crédito das contrapartes em uma operação securitizada tende a ser mais baixo, se comparado a uma emissão de dívida tradicional no mercado de capitais.

\subsubsection{Segregação de Riscos e Divulgação de Informações}

Conforme visto, a securitização visa a segregação de riscos que são inerentes à uma sociedade originadora de créditos, por meio da cessão de recebíveis para um veículo constituído especificamente para levantar recursos no mercado.

Este veículo, portanto, não deve possuir quaisquer tipos de passivos que não àqueles inerentes à própria operação de securitização. Desta forma, a totalidade dos recursos que o veículo receber será destinada ao pagamento dos títulos emitidos e dos custos da operação de securitização.

Além disso, o seu risco de falência deve ser considerado bem remoto, haja vista a ausência de qualquer passivo significativo.

Outro ponto positivo é o regime de informações relacionado às operações securitizadas. Tendo em vista os normativos expedidos pela CVM, o veículo de propósito específico deverá ser registrado junto à $\mathrm{CVM}^{87} \mathrm{e}$

\footnotetext{
${ }^{87}$ Nesse sentido, a Instrução CVM n ${ }^{\circ} .480$ prevê que as companhias securitizadoras de crédito devem ser registradas, pelo menos sob a categoria "B", e lista as informações que devem ser fornecidas pela companhia securitizadora à CVM, enquanto que, a Instrução CVM nº 356 prevê que o Fundo de Investimentos em Direitos Creditórios deve ser registrado junto à CVM.
} 
deverá prestar diversas informações aos investidores dos títulos e ao mercado em geral, especialmente com relação aos recebíveis que lastreiam os títulos emitidos nas operações de securitizações.

Além disso, dependendo da estrutura de securitização será necessária a preparação de um prospecto ${ }^{88}$ contendo diversas informações relacionados à própria operação e indicando os seus principais riscos. É possível também que seja necessária uma avaliação de risco dos valores mobiliários que serão objeto de oferta pública elaborado por uma agência de rating. ${ }^{89}$

Há, portanto, uma regulação sólida que faz com que os agentes do mercado divulguem informações aos potenciais investidores de títulos securitizados, para que estes tenham em mãos informações suficientes para decidirem se devem ou não aplicar seus recursos em títulos decorrentes de operações securitizadas.

\footnotetext{
${ }^{88}$ Caso a oferta pública de valores mobiliários ocorra de acordo com as disposições da Instrução CVM n ${ }^{\circ}$. 400, a elaboração de um prospecto será obrigatória, conforme disposto no art. 38 dessa Instrução.

${ }^{89}$ Observadas algumas exceções, a Instrução CVM n'o 356 prevê que cada classe ou série de quotas de FIDCs deve ser classificada por uma agência de rating.
} 


\section{ESTRURUTRA E PRINCIPAIS VEÍCULOS DE SECURITIZAÇÃO NO MERCADO DE CAPITAIS BRASILEIRO}

\subsection{Estrutura de uma operação de securitização}

Apesar de todo o conteúdo referente à securitização já apresentado no presente trabalho ser suficiente para conferir uma noção sobre a estrutura de uma operação securitizada, em nenhum momento este trabalho tomou o cuidado de abordar detalhadamente a estrutura de uma securitização. Em razão disso, esse será o foco do presente capítulo.

A securitização faz parte do universo das dívidas estruturadas, justamente pela sua complexidade e por sua capacidade de se adequar as necessidades individuais dos agentes que dela participam.

Nesse sentido, Uinie Caminha corrobora o entendimento acima: "Por não haver estrutura única legalmente imposta à securitização, e pela flexibilidade que pode ter, a securitização pode ser adaptada a diversas necessidades, ser mais complexa ou mais simples, envolver mais ou menos partes. $" 90$

Conforme é possível depreender do histórico e das características da securitização, as operações securitizadas evoluem constantemente de acordo com o desenvolvimento da própria economia e do arcabouço jurídico de cada país.

Em razão dos pontos acima, não parece prático tentar apresentar e explicar todas as estruturas de securitização existentes, razão pela qual, este trabalho buscará analisar somente a estrutura clássica de securitização. Ou seja, busca-se aqui, apresentar uma estrutura que possui traços semelhantes com o maior número de estruturas de securitização possíveis. ${ }^{91}$

\footnotetext{
${ }^{90}$ CAMINHA, Uinie. Securitização. $2^{\mathrm{a}}$ edição, São Paulo: Saraiva, 2007. p.100.

${ }^{91}$ VASCONCELLOS, Bernardo Fabião Barbeito de; MUNIZ, Igor. Op. Cit. p. 700.
} 
Independente da estrutura e do valor mobiliário a ser emitido vislumbra-se em linhas gerais que, para que seja possível caracterizar uma operação de securitização, é indispensável a presença de alguns elementos, são eles: (i) créditos, sejam eles presentes ou futuros, (ii) a cessão dos créditos mencionados no item (i) para um veículo de propósito específico, (iii) um veículo de propósito específico, o qual irá adquirir os créditos acima mencionados, e que pode ser constituído especificamente para uma única transação ou para diversas operações, sendo a prática de operações securitizadas a razão de sua existência, e (iv) a emissão, pelo veículo, de títulos que terão como lastro os créditos cedidos.

Em outras palavras, conforme é possível depreender dos ensinamentos de Fernando Schwarz Gaggini:

"De forma genérica, a operação de securitização de recebíveis compreende as seguintes etapas: uma empresa, possuidora de uma ampla carteira de créditos de vencimento futuro, desejando recebe-los antecipadamente, procede ao agrupamento de diversos créditos contra terceiros, ativos estes de semelhantes características e que possuam um histórico de pagamentos capaz de permitir uma análise de risco.

Como passo seguinte, é realizada a cessão destes créditos (os "recebíveis") para uma outra sociedade, constituída com o objetivo específico de ser a cessionária dos créditos e que, tendo estes como lastro, emitirá títulos e valores mobiliários no mercado de capitais.

(...)

Como terceira etapa, a securitizadora, com os recursos obtidos através da emissão dos títulos e valores mobiliários, liquidará a operação de cessão realizada pela sociedade originadora, de modo que esta receberá o valor dos recebíveis, atingindo seu objetivo de antecipar o recebimento dos mesmos.

(....)

Uma vez efetivado o pagamento da cessão de créditos junto à sociedade originadora, a sociedade securitizadora passa a ser legítima credora dos valores oriundos dos créditos, repassando-os aos investidores, que adquiriram os valores mobiliários de sua emissão."92

92 GAGGINI, Fernando Schwarz. Securitização de Recebíveis. São Paulo. Ed. Universitária de Direito, 2003. p. 29. 
Portanto, tem-se que na estrutura padrão de uma operação securitizada deve haver uma sociedade que detém direitos de crédito contra terceiros, sejam eles presentes ou futuros. Essa sociedade é chamada de originadora.

Em sequência, será constituído um veículo de propósito específico. No Brasil, usualmente são constituídos fundos de investimentos em direitos de creditórios ou sociedades de propósito específico na forma de companhias securitizadoras de crédito. ${ }^{93}$

Após os devidos trâmites legais para a constituição do veículo de propósito específico, passa-se para uma das etapas mais importantes e de maior risco jurídico da securitização, qual seja, a etapa de cessão dos créditos da sociedade originadora para o veículo de propósito específico. ${ }^{94}$

Realizada a cessão dos créditos e passando o veículo de propósito específico a ser o proprietário de tais direitos creditórios, passa-se para a última etapa, de emissão de valores mobiliários com lastro nos recebíveis adquiridos.

Trata-se do momento em que integrantes do sistema de distribuição de valores mobiliários colocam os títulos emitidos pelo veículo de propósito específico à disposição dos investidores que subscrevem e integralizam tais títulos. Os recursos decorrentes da integralização são utilizados para financiar a aquisição dos direitos creditórios pelo veículo de propósito específico.

Por fim, merece destaque que, apesar do presente trabalho apenas ter se proposto a analisar a estrutura padrão de uma operação de securitização, é inegável que o universo de operações que podem ser estruturadas é muito mais amplo do que aquilo que foi demonstrado aqui - cita-se como exemplo, a evolução das operações de securitização nos Estados Unidos da América,

\footnotetext{
${ }^{93}$ Os veículos aqui mencionados estão de acordo com as normas do sistema jurídica de Civil Law. Em países que utilizam a Common Law, um trust muitas vezes é o veículo de propósito específico utilizado nas operações de securitização. (VASCONCELLOS, Bernardo Fabião Barbeito de; MUNIZ, Igor. Op. Cit., p. 702.).

${ }^{94}$ Em razão de sua importância e riscos, a cessão dos créditos é objeto de estudo mais detalhado no próximo tópico.
} 
no período pré-crise que foi aqui apresentado-, de modo que, passadas as restrições legais e regulatórias, a criatividade dos agentes envolvidos na estruturação de uma operação securitizada acaba sendo a sua única limitação. ${ }^{95}$

\subsection{Da Cessão dos Créditos no âmbito de uma Operação Securitizada}

Explicada a estrutura padrão de uma operação securitizada, passa a ser importante analisar de forma mais detalhada um dos principais riscos jurídicos inerentes às operações de securitização.

Foi mencionado anteriormente que uma das etapas essenciais para a efetivação de uma operação securitizada é a cessão de recebíveis da sociedade originadora para o veículo de propósito específico.

A importância da cessão dos créditos ocorre devido ao fato de que a cessão será o negócio jurídico competente para transferir a titularidade dos recebíveis da sociedade originadora para o veículo de propósito específico.

Dessa forma, caso a cessão dos recebíveis não seja devidamente realizada, seguindo todos os requisitos e as previsões legais, haverá o risco de que a cessão possa ser anulada e os investidores, consequentemente, possam ser prejudicados.

Adicionalmente, a depender da estrutura de securitização desejada, será necessário observar além das regras impostas na Lei nº 10.406 , de 10 de janeiro de 2002 (Código Civil), normas infra-legais, como, por exemplo, no caso de instituições financeiras, que devem observar as Resoluções do Conselho Monetário Nacional $n^{\circ} .2 .686, n^{\circ} .2 .836$ e $n^{\circ} .2 .907$, expedidas pelo Banco Central do Brasil.

\footnotetext{
95 É possível, por exemplo, a estruturação de uma operação securitizada que envolva diversas sociedades originadoras, ao invés de uma só, ou então, a emissão de diversas classes distintas do mesmo valor mobiliário, apresentando diferentes riscos e retornos, estando ainda o pagamento de uma, subordinado ao recebimento pela outra classe.
} 
Nesse sentido, ao se falar de forma generalizada em securitização, é de extrema importância a observação das normas previstas no Código Civil, sendo necessário realizar de forma concomitante à cessão dos créditos alguns deveres de diligência, a fim de validar a cessão.

É necessário, portanto que se verifique se há alguma restrição à cessão dos créditos, seja ela legal ou convencionada entre os devedores dos créditos que serão cedidos e a sociedade originadora dos créditos. Havendo alguma restrição convencionada entre os devedores dos créditos cedidos e a sociedade originadora, será imprescindível solicitar a anuência dos devedores para a realização da cessão dos créditos, sem a qual, a cessão não poderá ser oposta aos devedores. ${ }^{96}$

Caso não exista qualquer vedação convencionada à cessão dos créditos entre os devedores e a sociedade originadora, mera notificação com recibo de ciência dos devedores informando acerca da cessão dos créditos para o veículo de propósito específico ${ }^{97}$ servirá para que a cessão seja eficaz contra os devedores.

Adicionalmente, a despeito da implicação de maiores custos para a operação, é necessário que o instrumento regendo a cessão do crédito seja registrado nos cartórios competentes, conforme previsão legal ${ }^{98}$, sem a qual, não será possível opor a cessão perante terceiros.

Por fim, merece destaque também a caracterização da True Sale no âmbito da cessão de créditos em uma operação de securitização, especialmente ao se considerar a sua relevância em outras legislações ao

\footnotetext{
${ }^{96} \mathrm{O}$ art. 286. do Código Civil prevê que: "O credor pode ceder o seu crédito, se a isso não se opuser a natureza da obrigação, a lei, ou a convenção com o devedor; a cláusula proibitiva da cessão não poderá ser oposta ao cessionário de boa-fé, se não constar do instrumento da obrigação."

97 "Art. 290. A cessão do crédito não tem eficácia em relação ao devedor, senão quando a este notificada; mas por notificado se tem o devedor que, em escrito público ou particular, se declarou ciente da cessão feita."

${ }^{98}$ Lei no ${ }^{\circ}$ 6.015/1973: "Art. 129. Estão sujeitos a registro, no Registro de Títulos e Documentos, para surtir efeitos em relação a terceiros:

(...)

$9^{\circ}$ ) os instrumentos de cessão de direitos e de créditos, de sub-rogação e de dação em pagamento."
} 
redor do mundo, em especial a norte-americana, que, como exposto possuiu grande influência no desenvolvimento da securitização.

\subsubsection{A True Sale}

A True Sale pode ser definida como uma cessão de créditos que possa ser legalmente classificada como final e definitiva, capaz de resistir à falência da sociedade originadora, sem que qualquer investidor seja por ela prejudicado, de forma que os créditos cedidos não integrem a massa falida da sociedade originadora. ${ }^{99}$

Ela é de suma importância para a caracterização da securitização, haja vista que ela traz segurança jurídica para que os investidores possam adquirir títulos emitidos por veículos de propósito específico sem ter que se preocupar com o risco de crédito da sociedade originadora.

Afinal, como apresentado anteriormente, um dos maiores benefícios da securitização para as sociedades originadoras e para os investidores é o fato de que os títulos objeto de securitização não devem ser afetados pelo risco de crédito da sociedade originadora.

Nesse ponto, a partir do momento em que os investidores devam se preocupar com a possibilidade da cessão dos créditos ser desfeita, e com a possibilidade dos créditos passarem a integrar eventual massa falida da sociedade originadora, a securitização seria descaracterizada por completo e se tornaria sem sentido a sua utilização no mercado de capitais.

Erik Oioili e Vanessa Faleiros indicam os requisitos necessários para a caracterização e para a descaracterização da True Sale no direito brasileiro:

"No direito brasileiro haverá true sale se os requisitos legais exigidos para cessão de créditos forem atendidos, podendo apenas ser invalidada ou tornada ineficaz a cessão de crédito pelo juízo competente caso seja realizada:

\footnotetext{
99 OIOLI, Erik F.; FALEIROS, Vanessa Zampolo. Transferência e Retenção de Riscos na Securitização. CANTIDIANO, Luiz Leonardo e MUNIZ, Igor (orgs.) Temas de Direito Bancário e do Mercado de Capitais. Rio de Janeiro: Renovar, 2014. p. 312.
} 
i) Em fraude contra credores, inclusive da massa falida, se o cedente estiver insolvente ou se com ela passar ao estado de insolvência;

ii) Em fraude à execução, caso a cessão de créditos seja realizada no curso de demanda judicial em face do cedente e esta transferência de ativo resulte na dificuldade da execução em juízo;

iii) Em fraude à execução fiscal, se o cedente tiver celebrado cessão de créditos em prejuízo à Fazenda Pública por crédito tributário inscrito como dívida ativa e não possuir outros bens para o pagamento do débito fiscal; e

iv) Em fraude falimentar, caso o único objetivo da cessão tenha sido prejudicar credores provando-se o consilium fraudis entre o cedente e terceiro, neste caso, o investidor, e o efetivo prejuízo sofrido pela massa falida." ${ }^{\prime 100}$.

Nota-se, portanto, que existe no direito brasileiro aspectos objetivos para a descaracterização de uma cessão de créditos como uma True Sale, sendo necessária a comprovação de fraude das partes envolvidas no negócio jurídico para que o mesmo seja anulado.

Curiosamente, o mesmo não pode ser dito sob a ótica da legislação norte-americana, aonde, devido à inexistência de parâmetros objetivos ${ }^{101}$ para sua caracterização ou descaracterização, a True Sale ganha contornos ainda mais relevantes.

Vale inclusive destacar que, devido aos aspectos objetivos elencados no direito brasileiro, é possível a realização de uma operação securitizada no mercado de capitais brasileiro em que a sociedade originadora retenha parte dos riscos, ou se comprometa a pagar, em caso de inadimplência dos devedores dos créditos cedidos, sem que isso descaracterize a True Sale.

Nos Estados Unidos da América, isso não seria possível, haja visto que a mera retenção de riscos por parte da sociedade originadora já pode ser o suficiente para algum tipo de questionamento da True Sale. ${ }^{102}$

Existe, portanto, maior flexibilidade para os agentes brasileiros estruturarem operações securitizadas, retendo alguma parte do risco que os investidores teriam, ao assumir a obrigação de pagar por eventuais créditos

\footnotetext{
100 OIOLI, Erik F.; FALEIROS, Vanessa Zampolo. Op. Cit., p. 312.

${ }^{101}$ OIOLI, Erik F.; FALEIROS, Vanessa Zampolo. Op. Cit., p. 313.

102 OIOLI, Erik F.; FALEIROS, Vanessa Zampolo. Op. Cit., p. 314.
} 
inadimplidos, o que, sem dúvidas, mostra-se benéfico para o desenvolvimento da securitização de créditos no Brasil.

Em contrapartida, a retenção de riscos por parte da sociedade originadora não a permite obter o benefício do financiamento off-balance, haja visto a sua necessidade de manter os riscos que retém evidenciados em seu balanço. ${ }^{103}$

\subsection{Principais Veículos de Securitização no Mercado de Capitais Brasileiro}

Passado o ponto de explicar uma estrutura padrão de uma operação securitizada cabe analisar sob a ótica do mercado de capitais brasileiro como essas estruturas podem ser colocadas à disposição dos agentes e dos investidores presentes no mercado de capitais brasileiro.

Nesse sentido, serão analisados os principais veículos de securitização disponíveis no mercado de capitais brasileiro, quais sejam os fundos de investimentos em direitos de creditórios e as companhias de securitização de créditos.

\subsubsection{Fundos de Investimento em Direitos Creditórios}

Conforme mencionado anteriormente, os Fundos de Investimentos em Direitos Creditórios (FIDCs) são um dos principais veículos de securitização presentes no mercado de capitais brasileiro ${ }^{104}$. Não obstante ser um importante veículo de securitização, dada a sua versatilidade e sua flexibilidade, os FIDCs também são utilizados em operações distintas da securitização.

\footnotetext{
103 OIOLI, Erik F.; FALEIROS, Vanessa Zampolo. Op. Cit., p. 310.

104 PARENTE, Norma Jonssen. Mercado de Capitais. In: CARVALHOSA, et. al. (org.). Coleção Tratado de Direito de Empresarial. Volume VI, $2^{\mathrm{a}}$ Ed. São Paulo: Thomson Reuters Brasil, 2018. p. 325.
} 
Em razão de sua complexidade e, por se tratar de um fundo de investimento - portanto, um ente com regime jurídico próprio -, faz-se necessário um estudo cauteloso sobre esse veículo, sendo necessário apresentar algumas das características básicas dos FIDCs, antes de passar para um estudo mais profundo.

\subsubsection{Natureza Jurídica}

Os FIDCs, assim como os demais fundos de investimentos possuem natureza jurídica de condomínio ${ }^{105}$.

Entende-se por isso que são uma comunhão de bens e direitos, dividida entre diversos proprietários, conforme a participação de cada um deles nessa comunhão de bens e direitos. Essa participação é representada por quotas dos fundos.

Mario Tavernand Martins de Carvalho, parafraseando Caio Mario da Silva Pereira, explica a natureza jurídica de um condomínio: "O condomínio é um direito real, que incide sobre determinados bens, e representa uma acepção de copropriedade (...). Consoante Caio Mario da Silva Pereira, "dáse condomínio, quando a mesma coisa pertence a mais de uma pessoa, cabendo a cada uma delas igual direito, idealmente, sobre o todo e cada uma de suas partes"'"106.

Dessa forma, por se tratar apenas de uma comunhão de recursos cuja propriedade é dividida entre mais de uma pessoa, os fundos de investimentos são considerados entes despersonalizados, isto é, entes sem personalidade jurídica.

\footnotetext{
${ }^{105}$ Vale destacar que existe controvérsia acerca da natureza jurídica dos fundos de investimentos. Nesse sentido, Mario Tavernand Martins de Carvalho indica o posicionamento de alguns dos mais importantes estudiosos do tema: "Entre os autores que defendem essa natureza condominial, podese citar Fernando Gaggini, Nelson Eizirik e Arnoldo Wald." (CARVALHO, Mario Tavernad Martins de. Regime Jurídico dos Fundos de Investimento. São Paulo: Quartier Latin, 2012. p.186) ${ }^{106}$ CARVALHO, Mario Tavernad Martins de. Regime Jurídico dos Fundos de Investimento. São Paulo: Quartier Latin, 2012. p.183
} 
E, justamente em razão de não possuir personalidade jurídica os FIDCs acabam possuindo certos benefícios fiscais, visto que não são contribuintes de diversos tributos como PIS/COFINS, IRPJ e CSLL. Destaca-se inclusive que esses benefícios fiscais acabam diminuindo os custos da operação e fazem com que o FIDC seja uma alternativa bem vista para a securitização. ${ }^{107}$

Não obstante a ausência de personalidade jurídica e os benefícios à ela inerentes, os fundos de investimento possuem plena capacidade para praticar os atos que lhe sejam necessários para alcançar os seus fins, desde que representados por seu administrador.

Nas palavras de Fernando Schwatz Gaggini:

"É imperativo reconhecer, portanto, que o fundo detém plena capacidade para adquirir e transferir direitos, estar em juízo e praticar atos comerciais, embora sempre representado pela pessoa do administrador, uma vez que não possui personalidade jurídica própria." 108

Nesse sentido, o administrador de um fundo é um agente considerado obrigatório para o seu funcionamento e para a sua manutenção, exercendo tarefas de gerência ${ }^{109}$, e preparando e fornecendo as informações necessárias do fundo aos seus quotistas, bem como, contratando outros prestadores de serviços essenciais ao funcionamento dos fundos.

Além do administrador, outros agentes possuem caráter essenciais nos fundos de investimentos. No caso dos FIDCs especificamente, tratam-se do custodiante, que deve prestar serviços relacionados à custódia dos direitos

\footnotetext{
${ }^{107}$ PARENTE, Norma Jonssen. Op. Cit. p. 325.

108 GAGGINI, Fernando Schwarcz. Fundos de Investimento no Direito Brasileiro. São Paulo: Liv. E Ed. Universitária de Direito, 2001. p. 53.

${ }^{109}$ As principais atribuições do administrador de um FIDC são listadas nos arts. 32 ao 37 da Instrução CVM nº.356.
} 
creditórios ${ }^{110}$, do auditor independente e da agência de rating (no caso de ofertas públicas de colocação de quotas). ${ }^{111}$

\title{
4.3.1.2. Estrutura Jurídica
}

Conforme ressaltado acima, os fundos podem adquirir e transferir direitos e, com base nesse raciocínio surgiram os FIDCs, que possuem como principal característica a aquisição de direitos creditórios, preferencialmente com deságio no valor da aquisição, e a consequente remuneração dos seus investidores com a realização dos direitos creditórios adquiridos.

Nessa linha, os FIDCs foram criados pela Resolução CMN nº . 2.907, de 29 de novembro de 2001, expedida pelo Banco Central do Brasil e, logo após, passaram a ser objeto de regulação também pela CVM, por meio da Instrução CVM nº. 356, de 17 de dezembro de 2001.

De acordo com a referida instrução, os FIDCs podem ser constituídos sob a forma de condomínio aberto ou fechado e a as suas quotas só podem ser subscritas por investidores qualificados ou investidores profissionais, a depender do caso ${ }^{112} 113$.

Rubens Vidigal Neto explica de forma didática os conceitos de um fundo constituído sob a forma de condomínio aberto e fechado:

\begin{abstract}
"Um FIDC "aberto" é aquele que admite a entrada - por meio da emissão de novas cotas - e a saída - por meio do resgate das cotas em circulação - dos investidores, a qualquer tempo, observados os procedimentos descritos em seu regulamento. O FIDC "fechado", por sua vez, somente admite a entrada de novos
\end{abstract}

\footnotetext{
${ }^{110}$ As principais atribuições do custodiante de um FIDC são listadas nos art. 38 da Instrução CVM $\mathrm{n}^{\mathrm{o}} .356$.

${ }^{111}$ Além dos prestadores de serviços essenciais mencionados acima, a Instrução CVM nº 356 prevê também agentes facultativos de prestação de serviços. São eles: o gestor, o consultor, o agente de cobrança de créditos inadimplidos e o agente de guarda de documentação.

${ }^{112} \mathrm{O}$ artigo $3^{\circ}$ da Instrução $\mathrm{CVM} \mathrm{n}^{\circ} .356$ prevê que: "Os fundos regulados por esta instrução terão as seguintes características:

I - serão constituídos na forma de condomínio aberto ou fechado;

II - somente poderão receber aplicações, bem como ter cotas negociadas no mercado secundário, quando o subscritor ou o adquirente das cotas for investidor qualificado; e "

${ }^{113}$ As definições de investidor qualificado e de investidor profissional se encontram na Instrução CVM nº. 554, de 17 de dezembro de 2014.
} 
investidores por meio da realização de uma nova oferta de cotas ou da negociação pelos cotistas, no mercado secundário, das cotas já existentes. As cotas dos FIDC "fechados" são resgatadas apenas ao final dos seus respectivos prazos de duração previstos no regulamento ou em razão da liquidação do FIDC, sendo permitida a amortização das cotas dos FIDC "fechados" sem a redução do número total de cotas detidas por cada investidor, nos termos de seu regulamento." 114

Essa espécie de fundo deve manter em seu portfólio, pelo menos $50 \%$ de seu patrimônio líquido ${ }^{115}$ em direitos creditórios ${ }^{116}$ (observadas as restrições impostas pela CVM) e o restante pode ser aplicado em títulos de emissão do Tesouro Nacional, dentre outros ${ }^{117}$, sendo possível também que o fundo realize operações compromissadas e realize operações com derivativos que busquem a proteção de suas posições à vista. ${ }^{118}$

Nota-se, portanto, que são um instrumento muito versátil para a realização de operações securitizadas, afinal, podem adquirir créditos oriundos de diversos segmentos e conseguem diminuir o risco de sua carteira de crédito com derivativos que possam proteger a sua posição nos créditos dos segmentos em que estejam comprados.

\footnotetext{
${ }^{114}$ NETO, Rubens Vidigal; A Securitização e a Indústria dos Fundos de Investimento em Direitos Creditórios. In. Direito do Mercado de Valores Mobiliários. $1^{\text {a }}$ Ed. Rio de Janeiro: Comissão de Valores Mobiliários, 2017, p. 640.

${ }^{115}$ Conforme prevê o artigo 40 da Instrução CVM no .356 : "Após 90 (noventa) dias do início de suas atividades, o fundo deve ter $50 \%$ (cinqüenta por cento), no mínimo, de seu patrimônio líquido representado por direitos creditórios, podendo a CVM, a seu exclusivo critério, prorrogar esse prazo por igual período, desde que o administrador apresente motivos que justifiquem a prorrogação."

${ }^{116}$ Conforme prevê o artigo $2^{\circ}$ da Instrução da CVM n 356, a definição de direitos creditórios é a seguinte: "direitos creditórios: os direitos e títulos representativos de crédito, originários de operações realizadas nos segmentos financeiro, comercial, industrial, imobiliário, de hipotecas, de arrendamento mercantil e de prestação de serviços, e os warrants, contratos e títulos referidos no $\S$ $8^{\circ}$ do art. 40, desta Instrução"

(...)

"Art. 40, § 8 : §8o As aplicações do fundo em warrants e em contratos mercantis de compra e venda de produtos, mercadorias e/ou serviços para entrega ou prestação futura, bem como em títulos ou certificados representativos desses contratos devem, sem prejuízo do atendimento das disposições da Resolução CMN no 2.801, de 7 de dezembro de 2000, e do disposto no $§ 4$ o deste artigo, contar com garantia de instituição financeira ou de sociedade seguradora, observada, nesse último caso, regulamentação específica da Superintendência de Seguros Privados - SUSEP, para fins de obtenção do registro automático previsto no $§ 10$ do art. 80 desta Instrução. "

${ }^{117}$ Conforme prevê o parágrafo primeiro do artigo 40 da Instrução CVM no .356 : "§1o Observado o disposto no caput deste artigo, o FIDC pode aplicar o remanescente de seu patrimônio líquido em títulos de emissão do Tesouro Nacional, títulos de emissão do Banco Central do Brasil, créditos securitizados pelo Tesouro Nacional, títulos de emissão de estados e municípios, certificados e recibos de depósito bancário e demais títulos, valores mobiliários e ativos financeiros de renda fixa, exceto cotas do Fundo de Desenvolvimento Social (FDS)".

${ }^{118}$ Conforme prevê o parágrafo primeiro do artigo 40 da Instrução CVM no ${ }^{\circ} .356$ : "\$2o É facultado ao fundo, ainda: I - realizar operações compromissadas; II - realizar operações em mercados de derivativos, desde que com o objetivo de proteger posições detidas à vista, até o limite dessas."
} 
Ainda, podem adquirir títulos públicos, como uma forma de contrabalancear o descasamento do fluxo de pagamento dos recebíveis com o pagamento da remuneração dos cotistas.

\subsubsection{Securitização via FIDC}

Via de regra, a estrutura de securitização de créditos por meio de um FIDC é semelhante à estrutura clássica apresentada anteriormente.

Na estrutura clássica de securitização via FIDC envolvendo apenas um cedente (monocedente), uma sociedade com uma carteira de recebíveis pulverizados de curto e longo prazo contrata um agente para estruturar o FIDC (usualmente um banco de investimentos), um administrador, para administrar o fundo, bem como, assessoria jurídica (usualmente externa) para preparar a estrutura jurídica aplicável e elaborar todos os documentos do FIDC e da oferta, considerando o caso concreto.

Após ficar tudo acertado entre as partes, o FIDC é constituído e a carteira de recebíveis da sociedade originadora é cedida ao fundo. Uma agência de rating classifica o risco dos créditos e do fundo e, mediante uma oferta pública, as quotas do FIDC são subscritas por investidores no mercado e os recursos decorrentes da subscrição das quotas são utilizados para pagar o preço de aquisição da carteira de recebíveis com algum deságio.

Os quotistas, consequentemente, são remunerados conforme o fundo aufere os rendimentos integrais dos créditos adquiridos (ou seja, com ágio, considerando o preço que foi pago pelo fundo) e passa a amortizar ou resgatar as quotas dos investidores, tudo conforme estabelecido no regulamento do fundo.

Destaca-se, contudo, que a estrutura descrita acima é bem simples, e que existem diversas estruturas mais sofisticadas no mercado, que conferem mais vantagens para ambos, quotistas e cedentes.

Dentre essas estruturas, algumas preveem a emissão de quotas de classe sênior (usualmente subscritas por investidores) e de classe 
subordinada, como quotas mezanino (possuem preferência de pagamento às quotas júniores) e quotas júnior (usualmente subscritas pelo cedente dos créditos).

E, em razão dessa estrutura com diferentes classes de quotas, sendo uma delas subscrita pela cedente dos créditos, é possível estabelecer no regulamento do FIDC que deve haver uma razão entre o número de quotas sêniores e o patrimônio líquido do fundo e que, se em algum momento essa razão ficar abaixo de determinados valores estabelecidos no regulamento, o cedente deverá subscrever novas quotas júniores - dessa forma, confere-se uma garantia adicional aos quotista seniores-, podendo subscrever tais quotas em moeda ou em direitos creditórios elegíveis nos termos do regulamento do fundo.

É possível estabelecer também que, sendo desrespeitada a razão entre as quotas sêniores e o patrimônio líquido do fundo, o cedente fica obrigado a recomprar parte dos créditos que foi cedido.

Por outro lado, também é possível estabelecer um teto (benchmark) para a remuneração que pode ser auferida pelos quotistas seniores, e que, o valor que exceder esse benchmark deverá remunerar os quotistas subordinados.

Nota-se, portanto, inúmeras formas de se estruturar um FIDC, comprovando a afirmação realizada anteriormente de que apenas a imaginação dos agentes impõe limites a estruturação de uma operação securitizada.

Por fim, merece destaque também que as quotas de FIDC podem ser negociados no mercado secundário, no entanto, tal mercado ainda se mostra incipiente, assim como a maioria dos mercados secundários de valores mobiliários no Brasil. 


\subsubsection{Fundos de Investimentos em Direitos Creditórios Não Padronizados}

Ao passo em que os FIDCs podem adquirir uma grande variedade de direitos creditórios, eles esbarram em algumas restrições legais com relação à aquisição de certos tipos de direitos creditórios, mais especificamente, com relação à ausência de previsão expressa na Instrução CVM nº 356, permitindo a aquisição de alguns direitos creditórios, como aqueles que estejam vencidos e não pagos, que sejam decorrentes de ações judiciais e precatórios, e que sejam decorrentes de obrigações futuras, dentre outros. ${ }^{119}$

Em razão da ausência de previsão expressa, diversas sociedades realizaram consultas à CVM, buscando saber se a aquisição desses direitos creditórios por um FIDC era possível.

Em vista do interesse dos agentes do mercado em adquirir esses tipos de crédito, a CVM baixou a Instrução CVM n ${ }^{\circ}$. 444, que criou os Fundos de Investimentos em Direitos Creditórios Não Padronizados (FIDC-NP) e regulou a aquisição de direitos creditórios considerados de risco mais alto por tais fundos.

\footnotetext{
${ }^{119}$ Nesse sentido, a Instrução CVM no .444 elenca os direitos creditórios que podem ser adquiridos por um FIDC-NP:

"§ $1^{\circ}$ Para efeito do disposto nesta Instrução, considera-se Não-Padronizado o FIDC cuja política de investimento permita a realização de aplicações, em quaisquer percentuais de seu patrimônio líquido, em direitos creditórios: I - que estejam vencidos e pendentes de pagamento quando de sua cessão para o fundo; II - decorrentes de receitas públicas originárias ou derivadas da União, dos Estados, do Distrito Federal e dos Municípios, bem como de suas autarquias e fundações; III - que resultem de ações judiciais em curso, constituam seu objeto de litígio, ou tenham sido judicialmente penhorados ou dados em garantia; IV - cuja constituição ou validade jurídica da cessão para o FIDC seja considerada um fator preponderante de risco; $\mathrm{V}$ - originados de empresas em processo de recuperação judicial ou extrajudicial; VI - de existência futura e montante desconhecido, desde que emergentes de relações já constituídas; e VII - de natureza diversa, não enquadráveis no disposto no inciso I do art. $2^{\circ}$ da Instrução $\mathrm{CVM} \mathrm{n}^{\circ} .356$, de 17 de dezembro de 2001 . $\S 2^{\circ}$ Será igualmente considerado Não-Padronizado: I - o FIDC cuja carteira de direitos creditórios tenha seu rendimento exposto a ativos que não os créditos cedidos ao fundo, tais como derivativos de crédito, quando não utilizados para proteção ou mitigação de risco; ou II - o Fundo de Investimento em Cotas de FIDC que realize aplicações em cotas de FIDC-NP. Art. $2^{\circ}$ A constituição e o funcionamento do FIDCNP reger-se-á pelo disposto na Instrução CVM n ${ }^{\circ} .356 / 01$, observadas as disposições da presente Instrução."
} 
As regras aplicáveis aos FIDC-NPs, no entanto, são muito semelhantes àquelas aplicáveis aos FIDCs, salvo algumas exceções, em especial, o fato de que os quotistas devem ser investidores profissionais.

São, portanto, mais um importante veículo de securitização, especialmente ao se considerar que, por meio dos FIDC-NPs, créditos que estão inadimplidos, créditos de empresas em recuperação judicial e créditos decorrentes de obrigações futuras podem ser objeto de securitização, oferecendo possíveis retornos mais altos do que a média, ao mesmo tempo em que oferecem riscos proporcionais aos seus retornos.

\subsubsection{Da Caracterização de FIDCs como veículos de securitização}

A despeito de tudo o que foi escrito acima, é importante destacar ainda existe certa discórdia entre parte da doutrina sobre a os FIDCs serem considerados veículos de securitização no Brasil. Nesse contexto, nasce a seguinte pergunta: seria tecnicamente correto afirmar que os FIDCs são veículos de securitização?

Dentre outros autores ${ }^{120}$, Fernando Schwartz Gaggini, apesar de reconhecer certas semelhanças, não se mostra convencido de que os FIDCs devem ser efetivamente considerados como veículos de securitização, conforme trechos abaixo:

\footnotetext{
"A operação envolvendo o fundo de recebíveis é muito semelhante à securitização. Assim, uma sociedade originadora de recebíveis transfere seus créditos a um fundo que, tendo tais ativos como lastro, emitirá cotas aos investidores e, com o dinheiro obtido com a venda das cotas, pagará a originadora pelos créditos cedidos.

Portanto, as operações são quase idênticas, distanciando-se mais visivelmente por substituir a sociedade de propósito específico por um fundo de investimento.

(...)

${ }^{120}$ Nesse sentido: "Colocando-se de outra forma, pode-se afirmar que os fundos de investimento em direitos creditórios são estruturas financeiras alternativas para as operações de securitização de recebíveis (...)" (FAGUNDES, João Paulo F. A. Os fundos de Investimento em Direitos Creditórios à luz das alterações introduzidas pela Instrução CVM 393. In Revista de Direito Mercantil, Industrial, Econômico e Financeiro. São Paulo: Malheiros, 2003, v. 132, p. 104)
} 
Entretanto, outras características diferenciam os institutos, dentre as quais, arrolamos algumas.

Inicialmente, há que se distinguir quanto à natureza jurídica. A securitizadora, como foi dito anteriormente, assume a forma de sociedade anônima, sendo, então, pessoa jurídica dotada de personalidade jurídica própria. O fundo, por sua vez, é uma comunhão de recursos, um condomínio, não possuindo personalidade jurídica.

(...)

Da mesma forma, a regulamentação vigente quanto aos fundos de recebíveis traça regras mais rígidas de composição de carteira do fundo, possuindo as securitizadoras maior liberdade e flexibilidade quanto aos recebíveis componentes de seu patrimônio.

Por fim, cabe assinalar que os fundos somente podem emitir cotas, ao passo que uma securitizadora tem a possibilidade de emitir um vasto rol de valores mobiliários." 121 .

Analisando os argumentos acima, de fato, não é possível discordar das distinções realizadas entre um fundo de investimento em direitos creditórios e uma companhia securitizadora de créditos, afinal, tratam-se de entes diferentes.

Como apresentado, um dos entes não possui personalidade jurídica, sendo apenas uma comunhão de recursos, enquanto o outro deve ser constituído sobre o tipo societário de sociedade anônima, portanto, um ente personalizado.

Adicionalmente, é necessário concordar com o argumento de que o único valor mobiliário que pode ser emitido pelos fundos de investimentos são as suas próprias quotas, enquanto as companhias securitizadoras possuem de fato um rol mais extenso de emissão de valores mobiliários.

Não parece, no entanto, razoável concordar que as operações realizadas por fundo de investimentos em direitos creditórios não devem ser consideradas securitizações, simplesmente devido às diferenças existentes entre um fundo de investimento e uma companhia securitizadora.

${ }^{121}$ GAGGINI, Fernando Scharwtz. Securitização de Recebíveis. Op. Cit. P.86-88. 
Afinal, por mais que um fundo de investimentos não tenha personalidade jurídica, o mesmo consegue desempenhar perfeitamente a função de um veículo de propósito específico em uma operação securitizada.

Ora, se a função de um veículo de propósito específico na securitização é de adquirir direitos creditórios e, posteriormente, emitir valores mobiliários com lastro em tais direitos creditórios adquiridos, tanto um fundo de investimentos em direitos creditórios, quanto uma securitizadora estão aptos para praticar essa função.

E, como apresentado, a securitização não pode ser caracterizada como um único negócio jurídico, mas sim como uma série de negócios jurídicos, dentre as quais é necessário que haja um veículo de propósito específico.

Em nenhum momento, no entanto, diz-se que o veículo de propósito específico deve ser necessariamente uma companhia securitizadora, ou, ainda, um ente personalizado.

Dizer algo nesse sentido, inclusive, traria consequências indesejadas ao mercado de capitais.

Seria causa para questionar a segurança jurídica de todos os negócios jurídicos que utilizam FIDCs e são classificados juridicamente como securitizações, sendo isso algo inimaginável para qualquer mercado de capitais do mundo, haja vista o apreço dos investidores por previsibilidade no mercado de capitais e segurança jurídica.

Tem razão, portanto, parte da doutrina quando evidencia as diferenças entre um fundo de investimento em direitos creditórios e uma companhia securitizadora. A visão aqui defendida, no entanto, é de que tanto os FIDCs, quanto as companhias securitizadoras são apenas veículos de propósito específico que podem desempenhar a mesma função em uma operação securitizada, não sendo, portanto, a distinção entre os veículos capaz de descaracterizar o instituto da securitização. Essa, inclusive é a posição de outra parte da doutrina. ${ }^{122}$

${ }^{122}$ CAMINHA, Uinie. Op. cit., pp. 104-105. 


\subsection{Companhias Securitizadoras de Crédito}

Além do FIDC, outro veículo de enorme relevância utilizado na securitização de créditos no mercado de capitais brasileiro é a companhia securitizadora de créditos.

Trata-se de sociedade cujo único objetivo é adquirir créditos de determinados segmentos, conforme será melhor estudado adiante, e que assume a função de veículo de propósito específico no contexto de uma operação securitizada, adquirindo direitos creditórios e emitindo determinados tipos de valores mobiliários para financiar essa aquisição.

Em razão da natureza de suas atividades e de previsão legal, as companhias securitizadoras de créditos devem assumir a forma de sociedades anônimas, estando sujeitas, portanto, às normas previstas na Lei $\mathrm{n}^{\circ}$. 6.404/1976, dentre outras normas expedidas pelo Banco Central do Brasil, a depender do caso concreto.

Será estudado adiante os segmentos nos quais essas companhias atuam, bem como, as diferenças regulatórias entre elas, e, de forma breve, os valores mobiliários por elas emitidos no contexto de uma operação securitizada no âmbito do mercado de capitais brasileiro.

\subsubsection{Companhias Securitizadoras de Créditos Financeiros}

As companhias securitizadoras de créditos financeiros sugiram com a Resolução do Conselho Monetário Nacional nº. 2.493, de 7 de maio de 1998, que passou a permitir que instituições financeiras cedessem créditos decorrentes de empréstimos, financiamentos e arrendamentos mercantis para companhias securitizadoras de créditos financeiros. ${ }^{123}$

\footnotetext{
${ }^{123}$ Nesse sentido, o artigo $1^{\circ}$ da Resolução CMN no.2.493/1998: "Art. $1^{\circ}$ Autorizar a cessão de créditos oriundos de operações de empréstimo, de financiamento e de arrendamento mercantil contratadas por bancos múltiplos, bancos comerciais, bancos de investimento, sociedades de crédito, financiamento e investimento, sociedades de crédito imobiliário, sociedades de arrendamento mercantil e companhias hipotecárias a sociedades anônimas que tenham por objeto exclusivo a aquisição de tais créditos. Parágrafo $1^{\circ} \mathrm{A}$ cessão de que trata este artigo somente pode ser realizada
} 
Antes do Conselho Monetário Nacional baixar essa resolução a cessão de créditos decorrentes de empréstimos, por instituições financeiras para sociedades que não integrassem o Sistema Financeiro Nacional era extremamente restrita, sendo por muito tempo vedada ${ }^{124}$ e, após um longo decurso de tempo permitida em casos excepcionais, mediante autorização do Banco Central do Brasil. ${ }^{125}$

Foi somente com a Resolução CMN nº 2.493 que o panorama com relação à cessão de créditos financeiros por instituições financeiras começou a se flexibilizar.

Alguns anos depois da Resolução $\mathrm{CMN} \mathrm{n}^{\circ}$. 2.493, novos normativos foram baixados, flexibilizando ainda mais a cessão de créditos financeiros por instituições financeiras para pessoas que não integrassem o Sistema Financeiro Nacional ${ }^{126}$. Foram também atualizadas as normas e as restrições aplicáveis à cessão de créditos financeiros para companhias securitizadoras de créditos financeiros ${ }^{127}$.

Nesse sentido, a despeito das companhias securitizadoras de créditos financeiros não estarem sujeitas à supervisão do Banco Central do Brasil, é inegável que as regras previstas na Resolução CMN nº 2.836 conseguiram influenciá-las diretamente, afinal, o Banco Central do Brasil regula e

com sociedade anônima que: I - contenha em sua denominação a expressão "Companhia Securitizadora de Créditos Financeiros".

${ }^{124}$ Nesse sentido, a Resolução CMN nº.523, admitia apenas que "(...) as sociedades de crédito, financiamento e investimento possam ceder ou alienar a outras sociedades da mesma categoria e a bancos comerciais, através de instrumento de cessão de crédito ou de outra forma jurídica adequada, os créditos oriundos de suas operações de financiamento ao consumidor ou usuário final de bens e serviços. "

${ }^{125}$ Nesse sentido, a Resolução CMN nº.1962, estabelecia, dentre outras regras relativas à cessão de créditos por instituições financeiras, que: "Art. 11. A cessão de créditos oriundos de operações de empréstimos, de financiamentos e de arrendamento mercantil para pessoas não integrantes do Sistema Financeiro Nacional pode ser admitida, excepcionalmente e mediante autorização, caso a caso, do Banco Central do Brasil. Parágrafo $1^{\circ}$ Para efeito do disposto neste artigo: I - somente serão admitidas as cessões de crédito na modalidade sem coobrigação da instituição cedente; II - não será permitida a recompra dos créditos cedidos; III - a liquidação das operações será efetuada à vista."

${ }^{126}$ Mais especificamente, trata-se da Resolução CMN no .2 .836 , que permitiu a alienação de direitos creditórios decorrentes de operações de empréstimo, financiamento e arrendamento mercantil, observado, dentre outras restrições, que tal alienação deveria ocorrer à vista, sem coobrigação e sem possibilidade de recompra dos créditos.

${ }^{127}$ Nesse sentido, foi baixada a Resolução CMN n'.2.686, de 26 de janeiro de 2000, em vigor até hoje, conforme alterada de tempos em tempos. 
supervisiona as instituições financeiras, que são justamente a principal contraparte das operações envolvendo as companhias securitizadoras de crédito financeiros.

Dentre as restrições estipuladas pelo BACEN, cita-se a restrição a forma como tais securitizadoras podem captar recursos (caso no Brasil, mediante a emissão de ações ou de debêntures não conversíveis e, caso no exterior, mediante a emissão de títulos ou valores mobiliários que estejam de acordo com a legislação vigente) ${ }^{128}$, e a prática de certos atos societários envolvendo a companhia securitizadora de créditos financeiros, enquanto a mesma tenha valores mobiliários emitidos que não tenham sido integralmente liquidados.

Não parece haver razão, contudo, para questionar o conteúdo previsto em tais normas, afinal, faz sentido que existam regramentos limitando a prática de atividades por companhias securitizadoras de créditos financeiros, posto tratar-se de companhias que surgiram com o objetivo de servir como um veículo de propósito específico no âmbito de uma operação securitizada, e que deve ter como única prática a aquisição de direitos creditórios e a emissão de valores mobiliários com lastro em tais direitos creditórios adquiridos.

Merece destaque que, por se tratar de uma companhia cuja principal atividade envolve emitir valores mobiliários no mercado de capitais, as companhias securitizadoras de créditos financeiros encontram-se sujeitas às normas da CVM.

Nesse ponto, as companhias securitizadoras de créditos financeiros devem se registrar junto à CVM como companhias abertas e prestar diversos tipos de informações com relação aos créditos financeiros adquiridos no âmbito de uma emissão. Via de regra, as securititizadoras registram-se sob a categoria "B", na CVM. No entanto, a depender do tipo de emissão que será

\footnotetext{
${ }^{128}$ Art. 1, parágrafo $1^{\circ}$, incisos "a" e "b", da Resolução CMN nº.2.686.
} 
realizada, será necessário o registro da companhia securitizadora de créditos financeiros sob a categoria "A". 129

Como visto, devido às restrições previstas pela Resolução CMN no . 2.686, as companhias securitizadoras de créditos financeiros ficam restritas a emitir debêntures não conversíveis em ações e ações.

No tocante à emissão de ações, esta não parece muito relevante considerando o escopo do presente trabalho, haja vista não ser muito observada na prática do mercado de capitais brasileiro. ${ }^{130}$

Já as debêntures emitidas por companhias securitizadoras de créditos financeiros são um instrumento visto com maior frequência no mercado de capitais brasileiro.

As companhias securititizadoras de créditos financeiros emitem debêntures não conversíveis para financiar a aquisição de créditos financeiros, os quais servem como lastro para remunerar os debenturistas.

Vale destacar que, nas emissões de debentures por companhias securitizadoras de créditos financeiro é possível incluir um mecanismo de subordinação semelhante àquele visto nos FIDCs, afinal, é permitido que a instituição cedente adquira debêntures subordinadas (i.e. debêntures cujo pagamento são subordinados ao pagamento de debêntures não subordinadas) mediante integralização em créditos financeiros.

Por fim, merece destaque que as debêntures emitidas por companhias de securitização de créditos financeiros não são um valor mobiliário emitido exclusivamente por essas companhias.

Na verdade, as debêntures são valores mobiliários muito comuns no mercado de capitais, regidas pela Lei das Sociedades por Ações ${ }^{131}$. A grande diferença das debêntures emitidas por companhias securitizadoras de créditos financeiros se dá no fato de que elas serão pagas com os recursos que vierem

\footnotetext{
${ }^{129}$ Caso a companhia securitizadora de créditos opte por emitir ações, ou opte por emitir debêntures nos termos da Instrução CVM n ${ }^{\circ} .400$, será necessário o registro de companhia sob categoria "A", conforme previsto na Instrução CVM n ${ }^{\circ} .480$.

${ }^{130}$ Merece destaque que, até o término da elaboração do presente trabalho não foi verificado sequer uma companhia de securitização de créditos financeiros listada na bolsa de valores brasileira, o que comprova a irrelevância desse tipo de oferta, sob o ponto de vista prático.

${ }^{131}$ Nesse sentido, ver artigos 52 até 71 da Lei das Sociedades por Ações.
} 
a ser auferidos pela securitizadora dos créditos financeiros que foram adquiridos com os recursos das próprias debêntures emitidas. Assumem, portanto os debenturistas, o risco de crédito dos devedores dos créditos financeiros, e não o risco de crédito da companhia securitizadora de créditos financeiros.

\subsubsection{Companhias Securitizadoras de Créditos Imobiliários}

Com relação às companhias securitizadoras de crédito imobiliário, estas foram criadas pela Lei $\mathrm{n}^{\mathrm{o}}$. 9.514 e possuem características bem semelhantes às companhias securitizadoras de créditos financeiros ${ }^{132}$.

Ambas devem ser constituídas sob a forma de sociedade por ações e não são consideradas instituições financeiras, adicionalmente, ambas têm como principal objetivo a securitização de direitos creditórios ${ }^{133}$. A maior diferença entre essas duas companhias de securitização reside nos créditos que serão objeto de securitização, e nos títulos emitidos no mercado de capitais.

Enquanto as companhias securitizadoras de créditos financeiros têm como objetivo a securitização de créditos financeiros, por meio da emissão de debêntures ou ações no mercado de capitais, as companhias securitizadoras de créditos imobiliários têm como objetivo a securitização de créditos imobiliários, por meio da emissão de Certificados de Recebíveis Imobiliários (CRIs).

\footnotetext{
${ }^{132}$ Inclusive, a Resolução $n^{\circ} .2 .686$, em seu artigo $6^{\circ}$, prevê a aplicação de parte dos dispositivos às companhias securitizadoras de créditos imobiliários.

${ }^{133}$ Nesse sentido, o art. $3^{\circ}$ da Lei $n^{\circ} .9 .514$ dispõe que: "As companhias securitizadoras de créditos imobiliários, instituições não financeiras constituídas sob a forma de sociedade por ações, terão por finalidade a aquisição e securitização desses créditos e a emissão e colocação, no mercado financeiro, de Certificados de Recebíveis Imobiliários, podendo emitir outros títulos de crédito, realizar negócios e prestar serviços compatíveis com as suas atividades."
} 


\subsubsection{Certificados de Recebíveis Imobiliários}

Com relação ao conceito de securitização de créditos imobiliários, este foi definido na própria Lei $\mathrm{n}^{\circ} .9 .514$, por meio de seu artigo $8^{\circ}$, que dispõe que:

"Art. $8^{\circ}$ A securitização de créditos imobiliários é a operação pela qual tais créditos são expressamente vinculados à emissão de uma série de títulos de crédito, mediante Termo de Securitização de Créditos, lavrado por uma companhia securitizadora, do qual constarão os seguintes elementos:

I - a identificação do devedor e o valor nominal de cada crédito que lastreie a emissão, com a individuação do imóvel a que esteja vinculado e a indicação do Cartório de Registro de Imóveis em que esteja registrado e respectiva matrícula, bem como a indicação do ato pelo qual o crédito foi cedido;

II - a identificação dos títulos emitidos;

III - a constituição de outras garantias de resgate dos títulos da série emitida, se for o caso.

Parágrafo único. Será permitida a securitização de créditos oriundos da alienação de unidades em edificação sob regime de incorporação nos moldes da Lei n ${ }^{\circ}$. 4.591, de 16 de dezembro de 1964."

Têm-se, portanto, que os títulos objeto da securitização imobiliária são os CRIs, que, conforme já explicado anteriormente, são títulos de crédito nominativos, com lastro em créditos imobiliários e que constituem promessa de pagamento em dinheiro ao seu titular. ${ }^{134}$ Estes são regulados principalmente pela Lei nº $.9 .514 / 1997$ e pela Instrução CVM nº ${ }^{4} 414$.

Portanto, em uma estrutura clássica de emissão de CRI, a companhia securitizadora de créditos imobiliários adquire determinados créditos imobiliários, empacota tais créditos em CRIs e emite tais CRIs no mercado de capitais. Com os recursos decorrentes da emissão dos CRIs, a companhia securitizadora de créditos imobiliários paga o preço de aquisição dos direitos crediórios adquiridos.

Nota-se, portanto, que os CRIs se assemelham aos mortgage backed securities, apresentados no início do trabalho como um dos títulos que mais

\footnotetext{
${ }^{134}$ Vide art. $6^{\circ}$ da Lei $n^{\circ} .9 .514 / 1997$
} 
contribuíram para o avanço da securitização nos Estados Unidos da América, justamente por se tratar de um título securitizado com lastro em créditos imobiliários e, por se tratar de um título securitizado que vem contribuindo para o aumento da securitização no Brasil.

Nesta seara, foi apresentado no início do trabalho dados que comprovam que os CRIs vêm apresentando grande crescimento no mercado de capitais brasileiro, e que vêm se tornando uma importante fonte de financiamento para diversas companhias, dentro e fora do segmento imobiliário.

Um ponto importante a ser mencionado, e que sem dúvida alguma vem contribuindo de forma intensa para o crescimento das emissões de CRI, decorre do atual entendimento da CVM sobre o conceito de "crédito imobiliário".

Conforme a Lei $n^{\circ} .9 .514$ preceitua, os CRIs têm como lastro créditos imobiliários. Ocorre que essa lei não define o conceito de crédito imobiliário, de forma que, não há uma definição legal sobre o que deveria constituir o lastro das emissões de CRI.

Tendo em vista essa lacuna na definição do conceito de crédito imobiliário e, considerando que, antes da Instrução CVM no $.476^{135}$ ser baixada, todas as emissões de CRIs eram registradas na CVM e, portanto, eram analisadas pela Superintendência de Registro de Valores Mobiliários (SRE), o conceito de crédito imobiliário foi sendo moldado pelo Colegiado da CVM e pela Superintendência de Registro de Valores Mobiliários.

Nesse sentido, por muito tempo se entendeu que crédito imobiliário seria aquele que tinha a sua origem decorrente de atividades ligadas ao financiamento do segmento imobiliário.

Ocorre que, com o desenvolvimento do mercado dos CRIs e a sua consolidação junto aos investidores, companhias que não atuavam no segmento imobiliário e que buscavam financiamentos para projetos

\footnotetext{
${ }^{135}$ A Instrução CVM no ${ }^{\circ} .476$ permite que diversos tipos de emissões sejam realizadas sem o prévio registro na CVM, observadas as suas restrições.
} 
imobiliários, começaram a pensar em estruturas alternativas de financiamento, de forma que lhes fossem possíveis assumir dívidas que servissem de lastro para CRIs.

Nesse sentido, o entendimento da CVM foi mudando ${ }^{136}$, passando a considerar possível a emissão de CRIs cujo lastro não se dava obrigatoriamente em créditos que possuíssem uma origem decorrente do segmento imobiliário (i.e. que os recebíveis que serão utilizados na remuneração dos titulares de CRI sejam de origem imobiliária), e sim, cuja destinação do crédito tenha fins de desenvolvimento de atividade imobiliária (i.e. os recebíveis que serão utilizados na remuneração dos CRI não serão decorrentes de atividades do segmento imobiliário, no entanto, os recursos obtidos em decorrência da emissão de CRIs serão utilizados no financiamento de atividades imobiliárias).

A partir desse momento, portanto, a CVM, de forma acertada, ajudou no desenvolvimento de um mercado que já estava em constante evolução, permitindo que mais companhias - e mais investidores também - se beneficiassem dos CRIs. ${ }^{137}$

\subsubsection{Companhias Securitizadoras de Créditos do Agronegócio}

Por fim, merecem destaque as companhias securitizadoras de créditos do agronegócio. Estas foram criadas pela Lei $n^{\circ}$. 11.076, de 30 de dezembro de 2014, e, assim como as demais companhias securitizadoras mencionadas acima, não são consideradas instituições financeiras e devem ser constituídas sob a forma de sociedade por ações. ${ }^{138}$

\footnotetext{
${ }^{136}$ Merecem destaque aqui alguns dos processos da CVM, que serviram de precedentes para a nova orientação da CVM: 19957.000587/2016-51 (decisão do Colegiado de 16 de agosto de 2016, conhecido como caso Cyrela) e 19957.001669/2016-13 (decisão do Colegiado de 30 de agosto de 2016, conhecido como caso Burger King).

${ }^{137}$ Destaca-se que, a despeito da mudança de posicionamento da CVM, para que seja realizada uma emissão, usando como base o critério da destinação de recursos, é necessário o cumprimento de algumas regras estabelecidas pelo Ofício-Circular CVM/SRE no. 01/18.

138 Vide art. 38 da Lei $n^{\circ} .11 .076$ : "As companhias securitizadoras de direitos creditórios do agronegócio são instituições não financeiras constituídas sob a forma de sociedade por ações e terão
} 
Devido à grande semelhança entre a companhia securitizadora de créditos do agronegócio e a companhia securitizadora de créditos imobiliário, a mesma não será objeto de estudo aprofundado, merecendo destaque que a maior diferença entre ambas se dá no fato de que a primeira tem por objeto a securitização de créditos decorrentes do agronegócio, enquanto a segunda tem por objeto a securitização de créditos imobiliários.

Ainda, as semelhanças não param por aí, os valores mobiliários por elas emitidos também tem características parecidas, apesar de existir algumas claras distinções, muito em razão da diferença entre os direitos creditórios objetos de securitização.

\subsubsection{Certificados de Recebíveis do Agronegócio}

Nessa seara, as companhias securitizadoras de créditos do agronegócio emitem Certificados de Recebíveis do Agronegócio (CRAs) que, assim como os CRIs, são títulos de crédito nominativos, de livre negociação e que representam uma promessa de pagamento em dinheiro, além de constituírem um título executivo extrajudicial. ${ }^{139}$

Diferem-se, portanto, nos direitos creditórios que servem de lastro para a emissão de cada um dos títulos. Por muito tempo as emissões de CRAs seguiram as regras previstas na Instrução CVM nº 414 , sendo realizadas adaptações necessárias conforme cada caso.

Em razão da ausência de normas específicas regulando os CRAs, as decisões do Colegiado da CVM a respeito desses valores mobiliários tiveram uma importância enorme nesse mercado e em suas práticas.

Cada caso julgado servia como um precedente, permitindo ou não a flexibilização das emissões. A possibilidade de emissão de CRAs utilizando como base o critério da destinação, ao invés do critério da origem, ou até a

por finalidade a aquisição e securitização desses direitos e a emissão e colocação de Certificados de Recebíveis do Agronegócio no mercado financeiro e de capitais."

${ }^{139}$ Vide art. 36 da Lei ${ }^{\circ} .11 .076 / 2004$. 
possibilidade de revolvência dos créditos lastro de CRAs, por exemplo, surgiram com as decisões do Colegiado da CVM.

Ocorre que, conforme reconhecido pela própria CVM, no Edital de Audiência Pública SMN nº. 01/17, os CRAs vinham alcançando uma nova dimensão, fazendo-se mais do que necessária sua regulamentação.

Consequentemente, a CVM baixou em $1^{\circ}$ de agosto de 2018, a Instrução CVM nº .600 , que, dentre algumas alterações à outras normas da CVM (incluindo a Instrução CVM nº.414), regulamentou a emissão de CRAs. Tal norma apenas entrou em vigor 90 dias após a sua publicação ${ }^{140}$, razão pela qual, não foi possível realizar uma análise profunda sobre a aplicação dos seus principais normativos.

Não obstante, parece importante ressaltar que essa nova norma tratou de temas importantes, consolidando entendimentos do Colegiado da CVM em matérias como a revolvência dos créditos lastro ${ }^{141}$ a possibilidade de emissão utilizando o critério de destinação de recursos ${ }^{142}$, dentre outras, e trazendo inovações como a definição do conceito de "direitos creditórios do agronegócio" e a possibilidade de securitizadoras realizarem ofertas públicas de até $\mathrm{R} \$ 100$ milhões sem a intermediação de uma instituições financeiras, o que tende a diminuir o custo de estruturação dessas ofertas..

Destaca-se que as inovações mencionadas acima são apenas algumas dentre as trazidas pela nova instrução. Ainda, por se tratar de uma norma recente e de grande importância ao mercado de capitais, as alterações trazidas por essa instrução merecem ser objeto de estudo aprofundado em trabalho específico sobre o tema, o que não é o caso do presente trabalho.

\footnotetext{
140 Vide art. 40 da Instrução CVM nº.600.

${ }^{141}$ Vide art. $7^{\circ}$ da Instrução CVM n ${ }^{\circ} .600$.

${ }^{142}$ Vide art. $3^{\circ}, \S 4^{\circ}$, inciso "II" da Instrução CVM n .600.
} 


\section{CONCLUSÃO}

Apresentada a evolução histórica da securitização, conceitos básicos sobre o mercado de capitais, as principais vantagens da securitização e os principais veículos e valores mobiliários emitidos em uma operação securitizada, parece claro que diversas conclusões sobre o assunto devem ser tomadas.

Dentre elas, e, a fim de seguir a ordem estabelecida neste trabalho, é fácil concluir que as operações securitizadas ainda não atingiram o seu pico no mercado de capitais brasileiro.

Tratam-se de operações de finanças estruturadas, de alta complexidade e muitas vezes decorrentes de complicados processos de engenharia financeira. Ainda, conforme evidenciado pela crise dos subprime, são operações que podem trazer riscos altos para os investidores e para o próprio mercado de capitais, caso os agentes nela envolvidos atuem de forma displicente.

No entanto, conforme foi demonstrado ao longo do presente trabalho, são operações que também podem trazer diversas vantagens para os agentes que estejam nela envolvidos, inclusive diminuindo os custos de captação de recursos.

Caso as operações securitizadas não tivessem tantas vantagens, não seriam elas um dos principais títulos de dívida emitidos ao redor do mundo.

Ainda, é possível concluir que há no Brasil um arcabouço jurídico sólido para a realização de operações securitizadas, bem como, não existem muitos exemplos de securitizações que deram errado e que trouxeram prejuízos aos seus investidores.

Justamente em razão desses fatores, vem percebendo-se um aumento gradual nas operações securitizadas, a despeito da crise financeira que assolou o Brasil nos últimos anos. Espera-se, portanto, que com uma 
economia mais forte, as operações securitizadas tenham uma tendência a crescer cada vez mais.

Destaca-se por outro lado que a ausência de um mercado secundário de títulos securitizados consolidado tende a limitar o crescimento desse mercado (bem como, de todos os outros).

Adicionalmente, o fato de grande parte das emissões de títulos decorrentes de operações securitizadas serem destinados à investidores profissionais e qualificados (muitas vezes devido aos custos mais altos que se tem ao realizar uma emissão destinada à investidores de varejo) também evita que essas operações alcancem um público maior.

Não obstante, é possível concluir que as operações securitizadas são uma excelente alternativa para sociedades com um forte fluxo de recebíveis e que desejam captar recursos por preços mais baixos que os habituais praticados em mercado. 


\section{BIBLIOGRAFIA}

ALAPHITA, T.; PEARCE, J.M. Securitization of Residential Solar Photovoltaic Assets: Costs, Risks and Uncertainty. Energy Policy. Volume 67 - Abri1/2014. p. 488-498.

ASSOCIAÇÃO BRASILEIRA DAS ENTIDADES DOS MERCADOS FINANCEIRO E DE CAPITAIS. Basileia III no Brasil. Acesso em 20 de outubro de 2018. Disponível em: < http://www.anbima.com.br/pt_br/informar/regulacao/informe-delegislacao/basileia-iii-no-brasil.htm\#tit2_3>.

BUCHANAN, Bonnie. Back to the future: 900 years of securitization. The Journal of Risk Finance, Vol.15, $4^{\text {a }}$ Ed., 2014. p. 316-333.

CAMINHA, Uinie. Securitização. 2a edição, São Paulo: Saraiva, 2007.

CANÇADO, Thais Romano; GARCIA, Fabio Gallo. Securitização no Brasil. São Paulo: Atlas, 2007.

CARVALHO, Mario Tavernad Martins de. Regime Jurídico dos Fundos de Investimento. São Paulo: Quartier Latin, 2012.

DINIZ, Gustavo Saad. Instrumentos de Capitalização Societária. In: Revista de Direito Privado, vol. 13, nº. 49, jan./mar. 2012. p. 313-330.

FABOZZI, Frank J.; KOTHARI, Vinod. Introduction to Securitization. New Jersey: Jon Wiley \& Sons, Inc., 2008. 
FAGUNDES, João Paulo F. A. Os fundos de Investimento em Direitos Creditórios à luz das alterações introduzidas pela Instrução CVM 393. In: Revista de Direito Mercantil, Industrial, Econômico e Financeiro. São Paulo: Malheiros, 2003, v. 132, p. 96-106.

FERNANDES, Mauricio Palmada, Et. al., A Securitização, Rating de Crédito e Valor de Empresas Emissoras. Disponível em http://www.anpad.org.br/admin/pdf/FIN91.pdf. Acesso em 13 de outubro de 2018 .

GAGGINI, Fernando Schwarcz. Fundos de Investimento no direito brasileiro. São Paulo: Liv. E. Ed. Universitária de Direito, 2001.

- Securitização de Recebíveis. São Paulo. Ed. Universitária de Direito, 2003.

GELBCKE, Ernesto Rubens et al. Manual de contabilidade societária: aplicável a todas as sociedades, de acordo com as normas internacionais e do CPC. 3.Ed. São Paulo: Atlas, 2018.

GOETZMANN, William N.; ROUWENHORST, K. Geert. The History of Financial Innovation. In: Carbon Finance, Environmental Market Solutions to Climate Change. Yale School of Forestry and Environmental Studies, 2008. p.18-43.

KENDALL, L. T.; FISHMAN, M. J. A Primer on Securitization. Cambridge, Mass: The MIT Press, 1996, p. 5-19.

KOHN, Meir. The Capital Market Before 1600. Dartmouth College. Department of Economics, fev. 1999. Disponível em: <https://cpb-us- 
e1.wpmucdn.com/sites.dartmouth.edu/dist/6/1163/files/2017/03/99-

06.pdf>. Acesso em 8 de setembro de 2018.

KOTHARI, Vinod. Securitization: The Financial Instrument of the Future. Singapura, Wiley, 2006.

McCONNELL, John J.; BUSER, Stephen A. The Origins and Evolution of the Market for Mortgage-Backed Securities. Annual Review of Financial Economics, n. 3, 2001. Disponível em: https://www.annualreviews.org/doi/pdf/10.1146/annurev-financial-102710144901. Acesso em 8 de setembro de 2018.

MEIBAK, Daniela; Debênture tira mercado de fundos de recebíveis. Valor Econômico. 3 de outubro de 2017. Disponível em: https://www.valor.com.br/financas/5142236/debenture-tira-mercado-defundos-de-recebiveis. Acesso em 4 de novembro de 2018.

MENDES, Hélio Rubens de Oliveira. Securitização de crédito e a lei $n^{o}$ 11.101/05. 2014. Tese (Doutorado em Direito Comercial) - Faculdade de Direito, Universidade de São Paulo, São Paulo, 2014.

OIOLI, Erik F.; FALEIROS, Vanessa Zampolo. Transferência e Retenção de Riscos na Securitização. In: CANTIDIANO, Luiz Leonardo e MUNIZ, Igor (orgs.) In: Temas de Direito Bancário e do Mercado de Capitais. Rio de Janeiro: Renovar, 2014. p. 301-320.

PARENTE, Norma Jonssen. Mercado de Capitais. In: CARVALHOSA, et. al. (org.). Coleção Tratado de Direito de Empresarial.Volume VI, ${ }^{\text {a }}$ Ed. São Paulo: Thomson Reuters Brasil, 2018. p. 325. 
PITTA, André Grunspun Pitta; FILHO, Valdir Carlos Pereira. Sistema Financeiro Nacional. In. Direito do Mercado de Valores Mobiliários. $1^{\text {a }}$ Ed. Rio de Janeiro: Comissão de Valores Mobiliários, 2017, p. 28-40.

PULINO, M. V. Z. O custo de capital em operações de securitização de recebíveis de empresas não-financeiras por meio da emissão de quotas de Fundos de Investimento em Direitos Creditórios - FIDCs. São Paulo, 2010. Dissertação (Mestrado em Administração de Empresas). Coordenadoria de Pós-Graduação, Fundação Getúlio Vargas, Escola de Administração de Empresas de São Paulo.

ROCHA, R. H. Mesbla Trust de Recebíveis de Cartão de Crédito S.A.: um caso de ensino. In: Revista de Economia e Administração, v. 12, n. 4, 2013. p. 508-529.

SCHWARCZ, Steven L. The Alchemy of Asset Securitization. 1 Stanford Journal of Law, Business \& Finance, 1994. p. 133-154 . Securitization Post-Enron. United States, North America: Duke University School of Law, 2004. p. 1539-1575.

SEGOVIANO, M. et al. Securitization: Lessons Learned and the Road Ahead. IMF Working Papers, 2013. Disponível em: <http://widgets.ebscohost.com/prod/customerspecific/s6115690/access/inde x.php?url=http\%3a\%2f\%2fsearch.ebscohost.com\%2flogin.aspx $\% 3$ fdirect $\%$ 3dtrue $\% 26 \mathrm{db} \% 3$ dedsgao\%26AN\%3dedsgcl.363191247\%26lang\%3dptbr\%26site\%3deds-live\%26scope\%3dsite>. Acesso em: 14 out. 2018. p. 8. 
UQBAR. Anuário UQBAR 2017 Finanças Estruturadas 2017 - Edição de 2017. Acesso em 4 de novembro de 2018. Disponível em: http://www.uqbar.com.br/download/UqbarAnuarioFE2017.pdf

UQBAR. Anuário UQBAR 2018 Certificados de Recebíveis do Agronegócio - $11^{\text {a }}$ Ed. 2018. Acesso em 4 de novembro de 2018. Disponível em: http://www.uqbar.com.br/download/UqbarAnuarioCRA2018.pdf

UQBAR. Anuário UQBAR 2018 Certificados de Recebiveis Imobiliários $11^{\text {a }}$ Ed. 2018. Acesso em 4 de novembro de 2018. Disponível em: http://www.uqbar.com.br/download/UqbarAnuarioCRI2018.pdf

UQBAR. Securitização. Disponível em < $\underline{\text { http://www.uqbar.com.br/instituci }}$ onal/emque/securitizacao.jsp. Acesso em 18 de novembro de 2018.

U.S. DEPARTMENT OF HOUSING AND URBAN DEVELOPMENT. The Secondary Market in Residential Mortgages. 1982. Disponível em: <https://www.huduser.gov/portal/publications/hsgfin/sec_mkt_1982.html.> Acesso em 31 de outubro de 2018:

VASCONCELLOS, Bernardo Fabião Barbeito de; MUNIZ, Igor. Securitização. In. Direito do Mercado de Valores Mobiliários. $1^{\text {a }}$ Ed. Rio de Janeiro: Comissão de Valores Mobiliários, 2017. 


\section{ANEXO II}

\section{A Monografia deve ser entregue até o dia 21 de novembro de 2018}

A presente Monografia, apresentada pelo (a) aluno (a) DANNY MALUA Y NE GRI

poderá ser submetida à exposição e defesa perante a Banca Examinadora designada pelo Departamento de Direito da PUC-Rio.

Rio de Janeiro, 21 de Novinbero de 2018

NORMA SONESEN PARENTE

Nome do (a) professor (a) orientador (a)

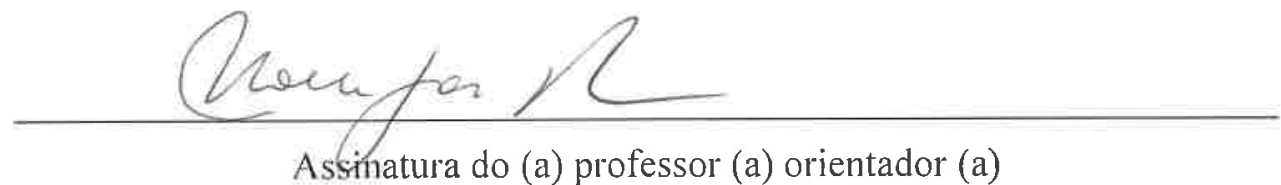

Assinatura do (a) professor (a) orientador (a)

O (A) autor (a) deste trabalho declara para todos os fins de Direito ser este um trabalho inédito e autoriza o Departamento de Direito da PUC-Rio a divulgá-lo, no todo ou em parte, resguardados os direitos autorais conforme legislação vigente.

Rio de Janeiro, 21 de Novenubro 2018.

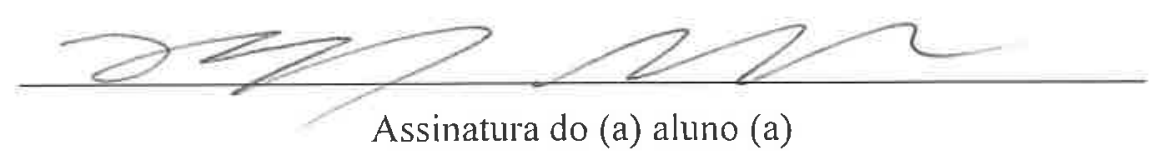

